\title{
Türkiye'nin ilk orman planlama ünitesindeki teknik ve yapısal değişimlerin 100 yıllık değerlendirilmesi
}

\author{
Centennial evaluation of technical and structural changes in the first forest planning \\ unit of Turkey
}

\author{
Abbas ŞAHİN ${ }^{1}$ \\ İnci ÇAĞLAYAN² \\ Hasan BÜYÜK ${ }^{1}$ \\ Halil KARADEMIR ${ }^{3}$ \\ Asalettin $\mathrm{AKSU}^{3}$ (iD \\ Halim ŞAHİN ${ }^{4}$
}

\footnotetext{
${ }^{1}$ Marmara Ormancılık Araștırma Enstitüsü Müdürlüğü, İstanbul

2 İstanbul Üniversitesi-Cerrahpaşa, Orman Fakültesi, İstanbul

${ }^{3}$ Orman Genel Müdürlüğü, Sakarya Orman Bölge Müdürlüğü, Adapazarı

${ }^{4}$ Orman Genel Müdürlüğü, İstanbul Orman Bölge Müdürlüğü, İstanbul
}

Sorumlu yazar (Corresponding author) Abbas SAHIN

abbassahin@yahoo.com

Geliş tarihi (Received)

03.08.2021

Kabul Tarihi (Accepted)

07.09.2021

Sorumlu editör (Corresponding editor) Mustafa BATUR

mustafabatur01@ogm.gov.tr

Atıf (To cite this article): Sahin, A., Cağlayan, İ., Büyük, H., Karademir, H., Aksu, A., Şahin, H (2022). Türkiye'nin ilk orman planlama ünitesindeki teknik ve yapısal değişimlerin yüz yıllık değerlendirilmesi . Ormancılık Araştırma Dergisi, 9 (1), 12-34 . DOI: 10.17568/ogmoad.977763

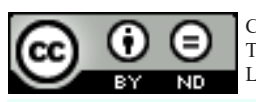

Creative Commons Atıf Crivetilemez 4.0 Ulushararas Lisansı ile lisanslanmıştır.
$\ddot{O} z$

Çalışmanın amacı, Türkiye'nin ilk orman amenajman planının düzenlendiği Hendek Mustafa Şeref Bey Ormanı için 1917-2015 döneminde yapılan sekiz orman amenajman planının teknik ve yapısal değişimlerinin karşılaştırmalı olarak ortaya konulmasıdır. Bu değişimler; planların dayandığ 1 yasal düzenlemeler, haritaların oluşturulması ve envanter yöntemleri ile planlama ilkeleri ve faydalanmanın düzenlenmesi bakımlarından değerlendirilmiştir. Planlar, ilk amenajman planı, istikşafı planlar, kat'i planlar, yaş sınıfları metoduna göre klasik ve ekosistem tabanlı planlar olmak üzere beş kategoriye ayrılmıştır. Planlamaların farklı dört kanun ve altı alt mevzuata göre yapıldığ belirlenmiştir. Plan ünitesinde sınırlar ve alan yedi kez önemli değişikliğe uğramıştır. İç taksimatı oluşturmada üç temel haritalama tekniği kullanılmıştır. Örnekleme yöntemi olarak bölmecik alan değerlendirmesi, tecrübe şeritleri, sistematik ve rastgele örnekleme kullanılmıştır. Amenajman metodu olarak yaş ve çap sınıfları uygulanmış, zamanla işletme sınıfı sayısı ve amaçlarında artış görülmüştür. Bilgi sistemleri ve teknolojik gelişmeler orman haritacılığının gelişmesine önemli katkılar sağlarken, orman envanteri ve planlanması konularında ise yeterli etkiyi gösterememiştir.

Anahtar Kelimeler: İlk orman amenajman planı, zamansal değişim, hukuk ve mevzuat değişiklikleri

\begin{abstract}
The aim of this study is to compare the technical and structural changes of the eight forest management plans made between 1917-2015 for Hendek Mustafa Şeref Bey Forest, which is the first forest management plan of Turkey. These changes were evaluated in terms of the legal regulations on which the plans are based, the creation of maps and inventory methods, planning principles and regulation of utilization. Plans are divided into five categories as the first forest management plan, exploratory plans, Final plans, classical and ecosystem-based plans by age classes method. It was determined that planning was made according to four different laws and six different regulations. The boundaries and areas of the planning unit have drastically changed seven times. Three basic mapping techniques were used in the structure of the compartment/sub-compartment. As the sampling method, compartmental area assessment, experience strips method, systematic and random sampling were used. Age and diameter classes were used as the management method. Over time, there has been an increase in the number of working circles and management objectives. While information systems and technological developments have made great contributions to development of forest mapping, they have not had a sufficient effect on forest inventory and planning.
\end{abstract}

Keywords: First forest management plan, temporal changes, law and legislation changes 


\section{Giriş}

Toplumlar, orman kaynaklarının rasyonel yönetimini bulmak için her dönemde yeni stratejiler ve yöntemler geliştirmektedir. Ortaçağ'dan 17. yüzyıl (yy) ortalarına kadar sanayi devrimi öncesi dönemde ormanlar bir yönetim planı veya stratejik planlama olmadan kullanılmaktadır. Sanayi Devrimi'nin (17. yy ortalarından 20. yy ortalarına kadar) başlamasıyla yeni sosyal ihtiyaçlar ve talepler ortaya çıkmış ve sonuç olarak doğal kaynakların yönetimi kökten değişmiştir (Paletto ve ark., 2008). Bu bağlamda, "modern" silvikültür kavramı geliştirilmiş ve ormanlar, gübreleme, egzotik tür kullanımı, yapay gençleştirme ve tıraşlama kesim vb. yeni teknikler ile yönetilmeye başlanmış, sonuç olarak saf ormanlar, yaşlı karışık ormanların yerini almıştır (Vos, 1996).

18. yy'ın başlarına kadar tarımın bir alt disiplini olarak görülen ormancılık, madencilik faaliyetlerinin genişlemesi ve sektörün çok fazla odun hammaddesine ihtiyaç duyması sonucunda bağımsız bir meslek disiplini olarak görülmüş ve yükselmiştir. Odun arz açığını karşılamak için araştırmacılar tarafından yeni yöntemlerin ve yaklaşımların ortaya konulması ormancılıkta yönetim, planlama, silvikültür, koruma ve faydalanma gibi ormanc1lık alt disiplinlerinin gelişimine katkı sağlamıştır (Agnoletti ve Anderson, 2000). Akdeniz ülkelerinde ise 3 ila 10 yıllık kısa rotasyonların kullanıldığ 1 baltalıklar koru ormanlarının yerini almıştır (Barbero ve ark., 1990). Sanayi Devriminden sonra (20. yy sonundan günümüze), kırsal toplumdan kent toplumuna geçişin bir sonucu olarak orman kaynağına ilişkin toplumsal alg1 değişmiştir (Mather, 2001). Kent toplumu pratik, faydacı değerlerin (maddi ve araçsal değerler) hâkim olduğu kırsal toplumun aksine, romantik, faydaci olmayan ormanı ve yaban hayatı değerlerini takdir etmeye başlamıştır (Kennedy, 1985). Bu süreçler sonucunda Sürdürülebilir Orman Yönetimi ve Ekosistem Hizmetleri Yönetimi gibi modern kavramlar ortaya çıkmış ve orman yönetimi ve planlamanın gelişimi analiz edilmiştir.

Ormanların planlanmasına ait her bir süreçteki değişiklikler, planlı ormancılığı tarihsel süreçte kavrayabilmek için anahtar faktörlerdir. Çünkü ormanlar tarihsel süreçteki sosyal, ekonomik, kültürel ve politik değişimlerin sonuçlarından etkilenmektedir (Chazdon ve ark., 2016). Bu nedenle, bu süreçlerin vaka çalışmaları ile ortaya konulması önemlidir. Vaka çalışmaları ile geçmiş ve şimdiki planlama yaklaşımları arasındaki farklılıklar gösterilebilir, farklılıkların temel nedenleri ortaya konulabilir, değerlendirilebilir ve planlı ormancılığ s şekillendiren süreçlerin olası tetikleyici güçleri ortaya çıkarılabilir. Planlı ormancılığg tetikleyen güçler, örneğin hukuki (yasa, yönetmelik, vb.), ekonomik ve sosyal eşitlik ilkeleri ve baskılar olabilir. Esas olarak insan tarafından yönlendirilen bu süreçleri incelemek için tarihsel süreçleri izlemek ve değerlendirmek büyük önem taşımaktadır (Southgate, 2019).

Ormanları planlama amaçları, değişen toplumsal ihtiyaçlara ve değerlere yanıt verdiğinden planlı ormancılığın ortaya çıkış zamanları ülkeden ülkeye farklılaşmaktadır (Lane ve McDonald, 2002). Örneğin planlı ormancılık Almanya'da 17. yy (Schmithüsen, 2013), Amerika'da 18. yy (Hall ve ark., 2002), Kanada'da 19. yy (Lane ve McDonald, 2002) ve Türkiye'de ise Osmanlı Devleti'nin son döneminde, yani 20. yy başlarında başlamıştır.

Osmanlı Devleti’nin son dönemlerinde orman kaynaklarının tahribinin ve aşırı kullanımının önüne geçilememiş ve bazı tedbirlerin alınması gereği ortaya çıkmıştır. Bunun dışında orman kaynaklarından ülke ekonomisine daha fazla katkı sağlamak için arayış içine girilmiştir. Bu amaçla, ormanların korunması ve süreklilik prensibine göre işletilmesi için en hızlı ve en köklü tedbirlerin alınması kararlaştırılmıştır. Bu nedenlerle, Osmanlı Devleti'nin 2. Meşrutiyet Hükümeti, I. Dünya savaşında müttefiki olan Avusturya- Macaristan İmparatorluğu'ndan orman müşaviri Hermann Veith'i fikirlerinden ve yapacağı tekliflerden faydalanmak amaciyla 1914 yılında Türkiye'ye getirmiştir. Veith, Türkiye'nin değişik bölgelerindeki ormanlarda incelemeler yapmış ve hazırladığ 1 raporlarda ormandan faydalanmanın Orman Amenajman Planları ile yapılmaS1 gerektiğini vurgulamıştır (Eraslan, 1955).

Orman amenajman planları veya orman araştırmaları ve raporları, orman kullanımındaki değişiklikleri ve ekolojik etkileri yeniden yapılandırmak için sıklıkla kullanılmıştır (Axelsson ve Östlund, 2001). Orman amenajman planları, ormancılıktaki ana planlama aracıdır. Planlar, Orman Mühendisleri tarafından yapılmakta ve belirli bir çalışma dönemine atıfta bulunarak düzenli olarak yeniden yazılmaktadır (Bürgi, 1999). Türkiye'de de orman amenajman planları, ülke ormanlarının sağlıklı ve sürdürülebilir bir şekilde yönetilmesini sağlamak için kullanılan en önemli araçlardan biridir.

Sakarya ilinde yer alan Hendek Mustafa Șeref Bey Ormanı, Türkiye'de orman amenajman planı yapılan ilk orman planlama ünitesidir. Planlama çalışmaları Osmanlı Devleti döneminde (1916-1917) gerçekleştirilmiş ve tamamlanan plan (Adapazarı Devlet Ormanlarının Hendek Nâhiyesi İdare Mıntıkasına Ait Amenajman Lâyiha-i Fenniyesidir) 25 Ocak 1918 tarihinde yürürlüğe konulmuştur. Pla- 
nın dayanağını oluşturan mevzuat düzenlemeleri Türkiye Cumhuriyeti Devleti kurulduktan sonra benzer içeriklerle yeniden düzenlenmiş; ilk planın yapımındaki teknik altlık ve yöntemler ise aynı şekilde ülkenin diğer orman alanlarının planlanmasında kullanılmaya devam edilmiştir. Eraslan (1982) ilk orman planlama çalışmalarının yapıldı ğı dönemi, Türkiye'de planlı ormancılığın ve orman amenajmanının doğması için gerekli hazırlıkların yapıldığı dönem olarak kabul etmektedir. Asan (2013a) ise bu dönemi ormanc1lık faaliyetlerinde sektörel planlamanın başlangıcı olarak görmektedir. Başkent ve ark., (2008) bu planlama yöntem ve sürecini Alman liderliğindeki neoklasik alan kontrol yönetimi olarak nitelendirmektedir.

Hendek Mustafa Şeref Bey Ormanı değişik adlar altında farklı büyüklükleri kapsayacak şekilde Türkiye Cumhuriyeti döneminde de ilk plandan sonra 7 kez planlanmıştır: Çamdağ Serisi I. Devre Amenajman Planı (1946), Kurtköy Serisi Kat'i Amenajman Planı (1955), Kurtköy Serisi Kat'i Amenajman Planı I. Revizyon (1969), Kurtköy Orman İşletme Şefliği Kurtköy Serisi Orman Amenajman Planı (1972), Kurtköy Orman İşletme Şefliği I. Yenileme (1994), Kurtköy Orman İşletme Şefliği II. Yenileme (2004) ve Çamdağ 1917 Orman İşletme Şefliği (2015) amenajman planlarıdır.

Yaklaşık 100 yıl içinde gerçekleştirilen planlama çalışmalarının Türkiye ormancılığına nasıl yön verdiğini ve ormanlardaki faydalanmaların plana bağlı olarak yapılmasının ormanları nitelik ve nicelik olarak nasıl etkilediğini ortaya koymak için geçmiş dönemlerdeki orman planlama çalışmalarını karşılaştırmalı bir şekilde ortaya konulması oldukça önemlidir. Ayrıca bu çalışmaların geçmiş dönemdeki uygulama sonuçları, toplumsal yap1 ve dinamikler ile ilişkilendirildiğinde ormancılığın sosyal ve ekonomik etkileri de ortaya konulmuş olacaktır. Tüm bunlar dikkate alındığında, geleneksel orman planlamanın tarihi, günümüz orman ekosistemlerini planlama süreçlerinin anlaşılması için çok önemlidir.

Çalışmada belgesel veri / kaynaklardan (orman amenajman planları ve haritaları) elde edilen kanıtlar ile şu üç temel soruya yanıt aranmıştır:

- Hendek Mustafa Şeref Bey Ormanı'nı 1917 y1lından 2015 yılına kadar planlamada ve ülke ormancılığ 1 için yürürlüğe konulan kanun ve alt mevzuatı hangileridir; nasıl ve ne zaman uygulanmışlardır?

- Orman haritalarının oluşturulması ve iç taksimat düzeninin kurulmasındaki değişimler nasıl gerçekleşmiştir? 1917 yılından günümüze kadar envanter ve veri toplama çalışmaları ile örnekleme yöntemlerinde hangi değişiklikler olmuştur?

- Ormanların işletme şekli ve işletme amaçları ile faydalanmanın düzenlenmesi esaslarına göre 1917 yılından günümüze hangi değişiklikler olmuştur?

Olası veri kaynağı türleri değerlendirildikten sonra, orman amenajman planları ve planların meşcere (orman) haritaları birincil bilgi kaynakları olarak seçilmiştir. Bu nedenle çalışma, yazılı belgelerin (orman amenajman planları) değerlendirilmesine dayanmaktadır. Çalışma konusu ile ilgili Osmanlı Türkçesi ile yazılmış yayınlar ve ilgili mevzuat taranarak kullanılacak olanların bugünkü Türkçeye tercümesi yapılmıştır. Çalışma alanı ile ilgili tüm orman amenajman planları ve meşcere haritaları temin edilerek zamansal analize konu olabilecek veriler elde edilmiştir. İlk amenajman planının yapılmasından günümüze kadarki sekiz plan farklılıklarını ve ortak yönlerini vurgulamak için karşılaştırmalı olarak incelenmiştir. Adı geçen planlar; kanun ve alt mevzuatı, plan süreleri, plan ünitesi alanı, harita tekniği ve ölçeği, harita altlı̆̆1, iç taksimat düzeni ve büyüklüğü, örnekleme yöntemi, örneklem şekli ve büyüklüğü, amenajman metodu, işletme amacı, işletme sınıfı, idare süresi, ağaç türü ve karışımı, meşcere gelişim çağı, bonitet, kapalılık ve silvikültürel durum açısından karşılaştırmalı olarak ele alınmıştır.

\section{Materyal ve Yöntem}

Çalışma alanı, plan ünitesinin ilk adıyla Hendek Mustafa Şeref Bey Ormant, yeni adiyla Çamdă̆ 1917 Orman İşletme Şefliği sınırlarını kapsamaktadır ve Sakarya ilinde yüz yılı aşkın bir süredir işletilmektedir. İlk Orman Amenajman Planı verilerine göre, Hendek Mustafa Şeref Bey Ormanı'nın alanı 7.197,04 hektar (ha) olup 7.049,24 ha ormanlık ve 147,80 ha orman dış1 alandır (Şekil 1b). Günümüzdeki adıyla Çamdağ1 1917 Orman İşletme Şefliği ise 2015 orman amenajman planına göre $6.640,4$ ha ormanlık ve $1.361,7$ ha ormancılık dışı olmak üzere toplam 8.002,1 ha (Şekil 1a) olup tamamı devlete aittir.

Hendek Mustafa Şeref Bey Ormanı (1917) planında ormanların ana ağaç türlerini kayın (Fagus orientalis), meşe (Quercus spp.) ve gürgen (Carpinus spp.) oluşturmakta; bu türlerin dişında titrekkavak (Populus tremula) ve sarıçam (Pinus sylvestris) ve sadece Çam Dağı'nda sınırlı alanlarda göknar (Abies spp.) meşcereleri de yayılış yapmaktadır. Plan ünitesinde serpili ve gruplar halinde gümüşi ıhlamur (Tilia argentea), karaağaç (Ulmus spp.), Anadolu kestanesi (Castanea sativa), çınar (Platanus spp.), 
kızılağaç (Alnus spp.) ve nadiren üvez (Sorbus spp.) türleri meşcere karışımlarında yer almaktadır. $\mathrm{Bu}$ orman ağaçları dışında kocayemiş (Arbutus spp.), funda (Erica arborea), çobanpüskülü (İlex spp.) ve orman gülü (Rhododendron ponticum) gibi çalı formundaki türlerden oluşan bitki toplulukları da yaygindir.

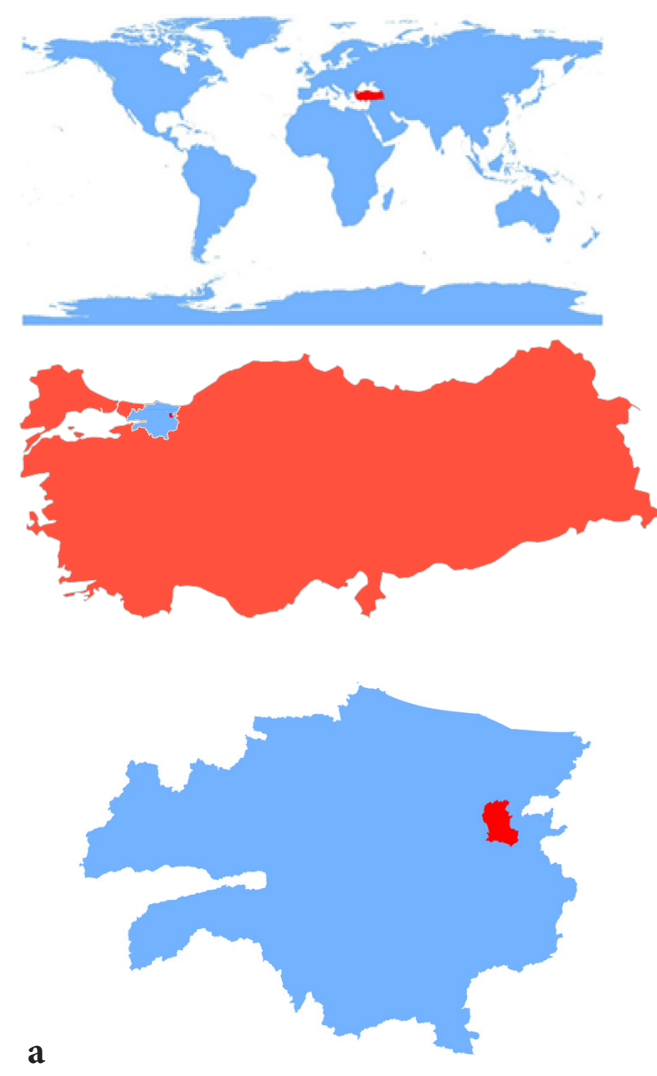

Şekil 1. (a) Çamdağı 1917 Orman İşletme Şefliği. (b) Hendek Mustafa Seref Bey Ormanı haritası Figure 1. (a) Çamdağ1 1917 Forest Sub-district Directorate. (b) Hendek Mustafa Şeref Bey Forest map
Çamdağ1 1917 Orman İşletme Şefliği (2015) planında ise kayın (Fagus spp.) sapsız meşe ( $Q u$ ercus petraea), Macar meşesi (Quercus frainetto), gürgen (Carpinus spp.), karaçam (Pinus nigra), gümüşi ıhlamur (Tilia argentea), Anadolu kestanesi (Castanea sativa) ve yalanc1 akasya (Robinia pseudoacacia) türlerinin ve tür gruplarının oluşturduğu 21 meşcere kompozisyonu bulunmaktadır.

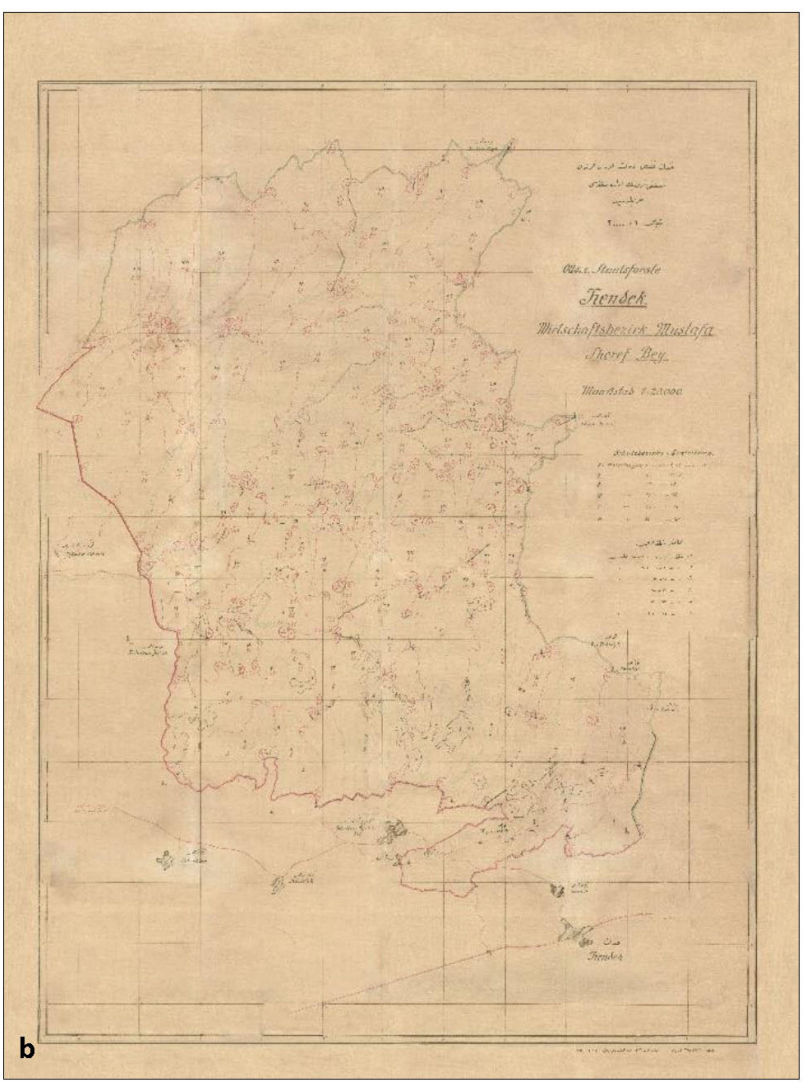

\subsection{Planların dayandığı yasal düzenlemeler}

Türkiye'de orman planlama çalışmalarının ilk plan yapımıyla birlikte hukuksal alt yapısı oluşturulmuş ve yaklaşık yüzyıl içerisinde kanun, yönetmelik, tebliğ ve izahname şeklinde çeşitli hukuki düzenlemeler yapılmıştır. Araştırmada, bu dönem yapılan sekiz plandan ve planların dayanaklarını oluşturan mevzuattan yararlanılmış, amenajman planları kanun ve alt mevzuat açısından karşılaştırılmış ve Şekil 2'de gösterilmiştir.

Kanun temelli ve planlı ormancılık 1917 yılında başlamış; plan yapımında Kanun, Yönetmelik, Tebliğ ve İzahname'lerden de yararlanılmıştır. Orman amenajman planları Osmanlı Devleti döneminde
Ormanların Usûl-i İâre-i Fenniyeleri Hakkında Kânun hükümlerine göre, Türkiye Cumhuriyeti Devleti döneminde ise Şekil 2'deki 504, 3116 ve 6831 sayılı kanunlara ve alt mevzuatına göre gerçekleştirilmiştir.

\subsection{Haritaların oluşturulması ve envanter}

Orman envanteri orman planlama amaçları için önemli bir bilgi kaynağıdır (Brosofske ve ark., 2014). Ormanların planlanmasındaki en önemli iş aşamalarından birkaçını; planlanacak orman alanının konumsal olarak sinırlarının belirlenmesi, alanın işletme amaçları ve koruma hedefleri doğrultusunda iç taksimat düzeninin kurulması ve belirlenen amaçlara uygun örnekleme yöntemleri 


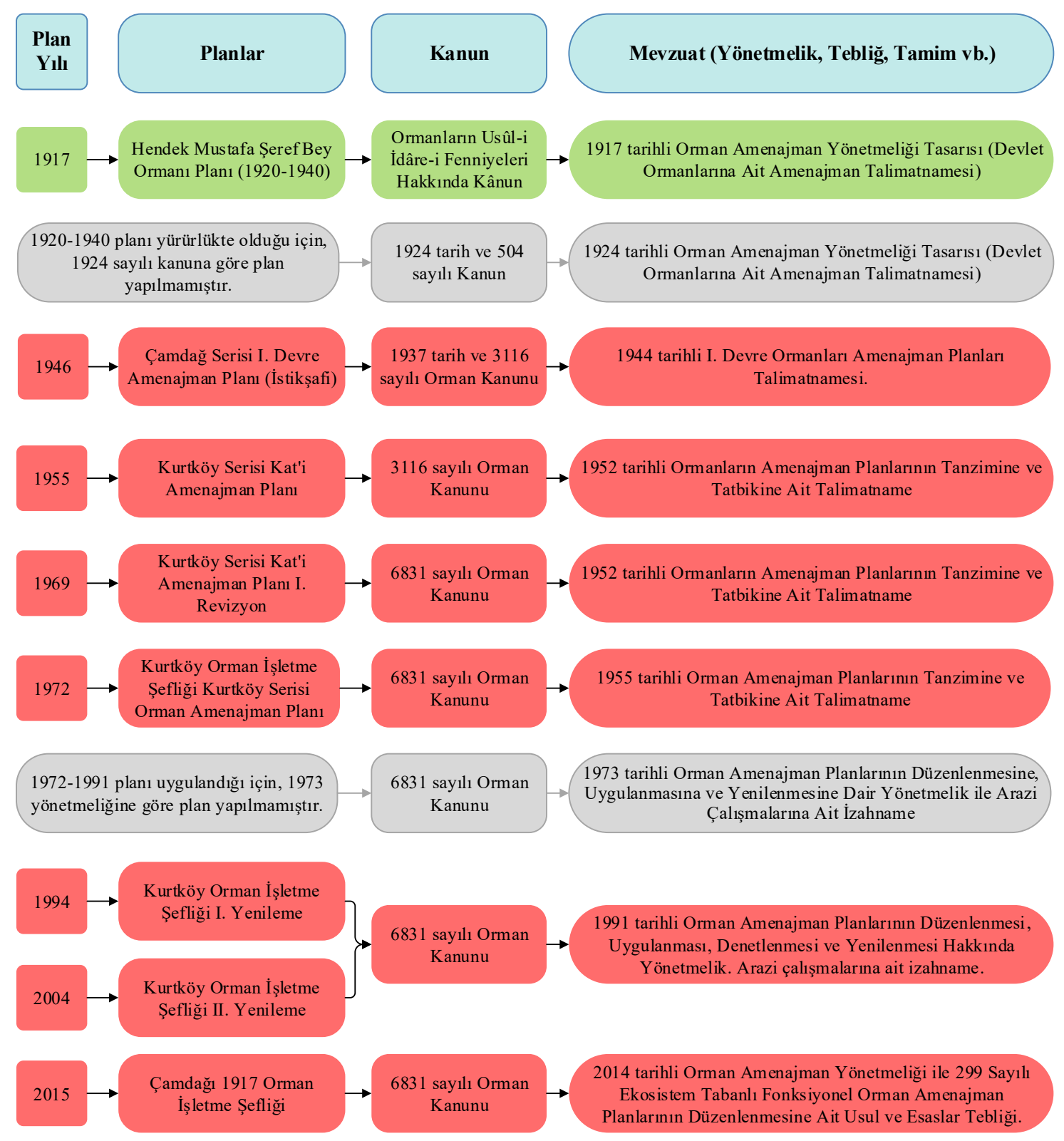

Şekil 2. Hendek orman amenajman planlarının mevzuata göre tarihsel süreci

Figure 2. The historical process of Hendek forest management plans according to laws

kullanılarak, orman envanterinin yapılması konuları oluşturmaktadır.

Çalışmada, sekiz plan döneminde yapılan orman amenajman planları, orman envanteri ana başlı̆̆ altında toplanan yedi alt başlığa ayrılarak incelenmiştir. Plan süresi, plan ünitesi alanı, harita tekniği ve ölçeği, harita altlığı, iç taksimat düzeni ve büyüklüğü ile örnekleme yöntemi, örnekleme şekli ve büyüklüğü bakımından farklılıkları karşılaştırmalı olarak Şekil 3’te verilmiştir.

\subsection{Planlama ilkeleri ve faydalanmanın düzenlenmesi}

Planlar, bu bölümde dokuz alt başlığa ayrılarak incelenmiştir (Tablo 1 ve Tablo 2). Orman amenajman planlarına ait amenajman metotları, işletme amaçları, işletme sınıfları ve idare süreleri açısından karşılaştırılması Tablo 1'de; ağaç türü, meşcere gelişim çağ 1 , bonitet, kapalılık ve silvikültürel durum karşılaştırması ise Tablo 2'de verilmiştir. 


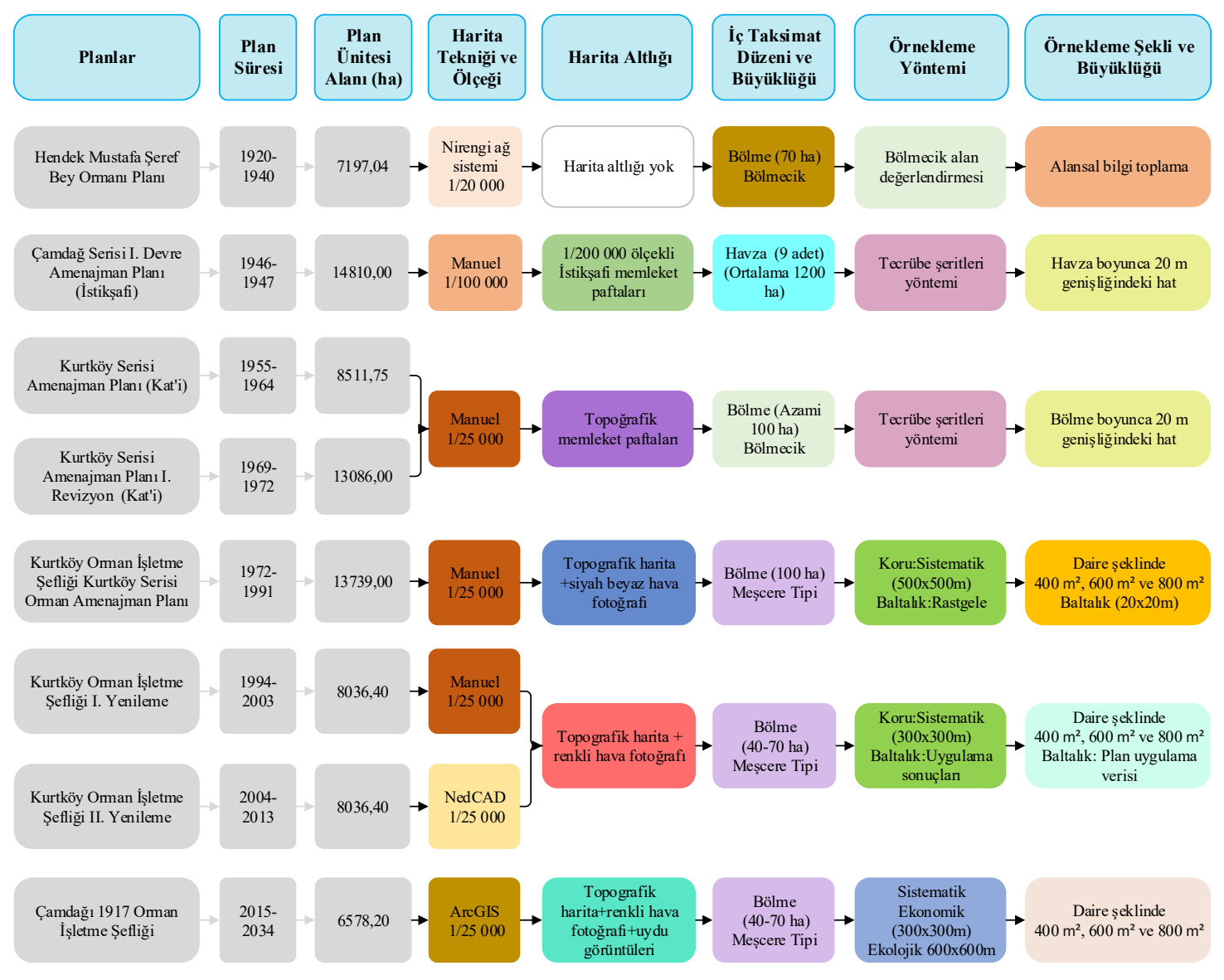

Şekil 3. Plan Ünitesinin iç taksimatlandırma ve örnekleme sistematiği

Figure 3. Compartment/Sub-compartment outline and sampling method of the Planning Unit

\section{Bulgular}

\subsection{Planların dayandığı yasal düzenlemeler}

Hendek Mustafa Şeref Bey Ormanı amenajman planlama çalışmalarının yasal dayanağını oluşturan "Ormanların Usûl-i İdâre-i Fenniyeleri Hakkında Kânun”, Takvim-i Vekâyi’nin (bugünkü Resmi Gazete) 24 Nisan 1917 tarih ve 2863 say1sında Sultan Mehmed Reşat, Sadrazam Mehmed Talat, Maliye Nazırı Cavid ile Ticaret ve Ziraat Nazırı Mustafa Şeref'in imzaları ile yürürlüğe girmiştir (Şekil 4a ve 4b). Ülkemizde ilk orman planlama çalışmaları Osmanlı Devleti döneminde ve bu Kanun'a dayanılarak gerçekleştirilmiştir. Kanun'un öngördüğü Orman Amenajman Yönetmeliği Tasarısı (Devlet Ormanlarına Ait Amenajman Talimatnamesi) Avusturyalı ormancılık müşaviri Hermann Veith tarafından hazırlanmıştır (Kutluk, 1948; Asan, 2013b).

1917 y1lında yürürlüğe giren bu Kanun, Osmanlı Devleti'ne ait ormanların planlı yönetilmesine ve işletilmesine olanak sağlayan planlama ile ilgili ilk hukuki düzenlemedir (Eraslan 1955; Asan, 2013b). 1924 yılında 504 sayılı kanuna ek olarak 526 sayılı kanun (526 SK) çıkarılmış (Eler, 2008) aynı yıl yürürlüğe girmişlerdir. 504 SK ve 526 SK, 1937 tarih ve 3116 sayılı Orman Kanunu (3116 SK) yürürlüğe girinceye kadar (13 yıl) yürürlükte kalmıştır. Hendek Mustafa Şeref Bey Ormanı Orman Amenajman Planı 1940 yılına kadar yürürlükte olduğu için 1924 yılında düzenlenen mevzuat hükümlerine göre yeni plan yapılmamıştır.

1941 yılında tüm ülke ormanlarının kısa bir sürede amenajman planlarına sahip olması amacıyla Türkiye Ormanları Amenajman Planlarının Sür'atIe Íkmaline Dair Talimatname adl yeni bir mevzuat çıkarılmıştır. Beklenen sonuç elde edilemediğinden üç yıl sonra planlama çalışmalarını daha fazla hızlandırmak için 1944 tarihli Birinci Devre Amenajman Işsleri Talimatnamesi çıkarılmıştır (Şahin, 2020). Çamdağ Serisi I. Devre Amenajman Planı (1946), 1944 tarihli I. Devre Ormanları Amenajman Planları Talimatnamesi 'ne göre düzenlenmiştir.

Kurtköy Serisi Kat'i Amenajman Planı (1955) ile 
Tablo 1. Planların ormanlardan faydalanmayı düzenlemede esas alınan kavramlara göre karşılaștırılması

Table 1. Comparison of management plans according to the concepts based on management regulations

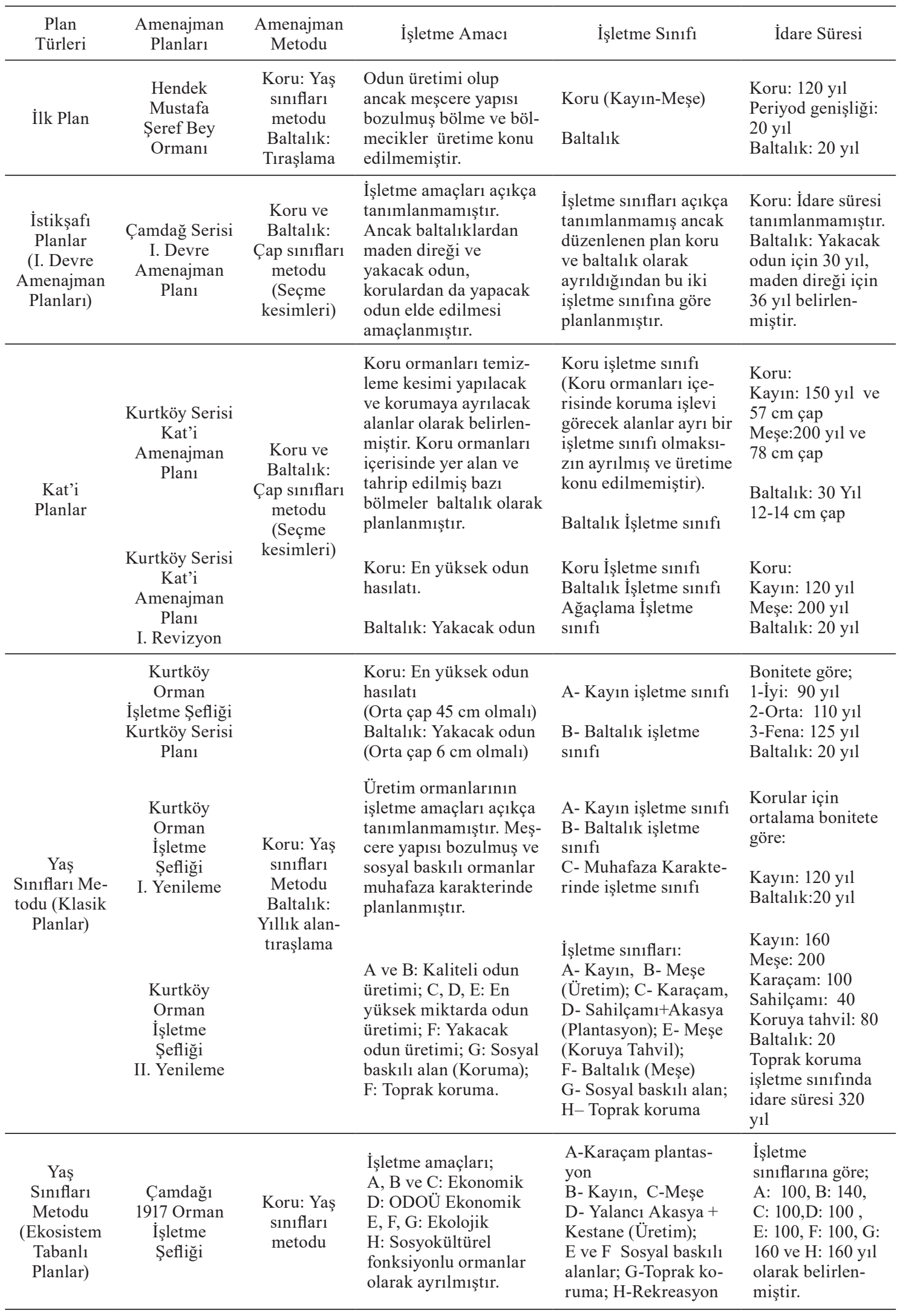


Tablo 2. Planların ormanlardan faydalanmayı düzenlemede esas alınan kavramlara göre karşılaştırılması

Table 2. Comparison of management plans according to the concepts based on management regulations

\begin{tabular}{|c|c|c|c|c|}
\hline $\begin{array}{l}\text { Plan } \\
\text { Türleri }\end{array}$ & $\begin{array}{l}\text { Amenajman } \\
\text { Planlar1 }\end{array}$ & $\begin{array}{c}\text { Ağaç Türü, Meşcere Gelişim Çağ } 1 \text { ve } \\
\text { Kapalılık Durumu }\end{array}$ & $\begin{array}{l}\text { Silvikültürel } \\
\text { Durum }\end{array}$ & Bonitet \\
\hline İlk Plan & $\begin{array}{l}\text { Hendek } \\
\text { Mustafa } \\
\text { Şeref Bey } \\
\text { Orman1 }\end{array}$ & $\begin{array}{l}\text { Her bölme ya da bölmecik ayrı bir işlem ünitesi } \\
\text { olarak belirlenmiştir. Meşcere tipi ve gelişim çağı } \\
\text { kavramı yoktur. Her bölmecik için ağaç türü ya } \\
\text { da tür karışımı tanımlanmıştır. Ana ağaç türlerini } \\
\text { kayın, meşe ve gürgen oluşturmaktadır. Kavak, } \\
\text { sarıçam meşcereleri ile sadece Çam dağında sınırlı } \\
\text { bir alanda göknar mevcuttur. Kapalılık "kesafet" } \\
\text { adı ile yer almaktadır. Meşcereler, } 1 \text { - 0,9: Tam } \\
\text { kapalı, } \\
0,8 \text { - 0,6: Seyrek, } 0,5 \text { - 0,3: Pek seyrek olarak sınıf- } \\
\text { landırılmıştır. }\end{array}$ & $\begin{array}{l}\text { Her bölme- } \\
\text { cik ayrı bir } \\
\text { silvikültürel } \\
\text { işlem ünitesi } \\
\text { kabul edilerek } \\
\text { silvikültürel } \\
\text { uygulamalar } \\
\text { önerilmiştir. }\end{array}$ & $\begin{array}{l}\text { Meşcere orta } \\
\text { boyu esas } \\
\text { alınmış ve } \\
\text { bonitetin sap- } \\
\text { tanmasında } \\
\text { Feissmantel ve } \\
\text { Pressler'in bo- } \\
\text { nitet tablolar1 } \\
\text { kullanılmıştır. }\end{array}$ \\
\hline $\begin{array}{l}\text { İstikşafi } \\
\text { Planlar } \\
\text { (I. Devre } \\
\text { Amenaj- } \\
\text { man } \\
\text { Planları) }\end{array}$ & $\begin{array}{l}\text { Çamdağ } \\
\text { Serisi } \\
\text { I. Devre } \\
\text { Amenajman } \\
\text { Planı }\end{array}$ & $\begin{array}{l}\text { Meşcere tipi ve gelişim çağı kavramı bulunmamak- } \\
\text { tadır. Koru ormanlarının ana ağaç türünü kayın } \\
\text { oluşturmaktadır. Kayına yer yer meşe ve kavak ka- } \\
\text { rışmaktadır. Baltalık ormanlarının asli ağaç türünü } \\
\text { ise meşe oluşturmaktadır. Havza bazında "ondalık" } \\
\text { düzeyinde tanımlanmıştır. }\end{array}$ & $\begin{array}{l}\text { Silvikültürel } \\
\text { müdahaleler } \\
\text { ayrıntılı } \\
\text { verilmemiştir. } \\
\text { Üretimle ilgili } \\
\text { ifadeler yoktur. }\end{array}$ & $\begin{array}{l}\text { Bonitet ile il- } \\
\text { gili çalışmalar } \\
\text { yapılmamıştır. }\end{array}$ \\
\hline $\begin{array}{l}\text { Kat'i } \\
\text { Planlar }\end{array}$ & $\begin{array}{l}\text { Kurtköy } \\
\text { Serisi Kat'i } \\
\text { Amenajman } \\
\quad \text { Planı } \\
\text { I. Revizyon }\end{array}$ & $\begin{array}{l}\text { Meşcere tipi ve gelişim çağı kavramı bulunmamak- } \\
\text { tadır. Koru ormanlarının ağaç türlerinin; \% 69'u } \\
\text { kayın, \% 28'i meşe, \%3'ü göknar, 1hlamur kavak } \\
\text { ve kestane türlerinden oluşmaktadır. Baltalık } \\
\text { ormanlarının asli türleri meşe, kayın ve gürgen. } \\
\text { Kapalılık } 0,1 \text {-1,0 arasında ondalı düzeyinde sap- } \\
\text { tanmıştır. Meşcerelerin kapalılığı korularda } 0,4-0,8 \\
\text { arasındadır. } \\
\text { Meşcere tipi ve gelişim çağı kavramı bulunmamak- } \\
\text { tadır. Koru ormanlarının \% 77,7'si kayın, \%15,1'i } \\
\text { meşe, \% 6,2'si gürgen ve \% 1'i ise 1hlamur, kavak, } \\
\text { kestane göknar, kara ağaç ve kızıllağaç türlerinden } \\
\text { oluşmaktadır. Baltalık ormanlarının \% 49'u kayın, } \\
\text { \% 42'si meşe, \% 6'sı gürgen, ve \% 3'ü ise kavaktır. } \\
\text { Kapalılık 0,1 -1,0 arasında ondalık düzeyinde sap- } \\
\text { tanmıştır. Meşcerelerin kapalılıkları } 0,2 \text { ile } 0,9 \\
\text { arasında saptanmıştır. }\end{array}$ & $\begin{array}{l}\text { Silvikültürel } \\
\text { durum ifadeleri } \\
\text { her bölmecik/ } \\
\text { meşcere için } \\
\text { ayrı ayrı } \\
\text { tanımlanmıştır. }\end{array}$ & $\begin{array}{l}\text { Bonitet ile il- } \\
\text { gili çalışmalar } \\
\text { yer almamıştır. }\end{array}$ \\
\hline $\begin{array}{l}\text { Yaş } \\
\text { Sinıfları } \\
\text { Metodu } \\
\text { (Klasik } \\
\text { Planlar) }\end{array}$ & $\begin{array}{l}\text { Kurtköy } \\
\text { Orm. İşl. } \\
\text { Şefliği } \\
\text { Kurtköy } \\
\text { Serisi Planı }\end{array}$ & 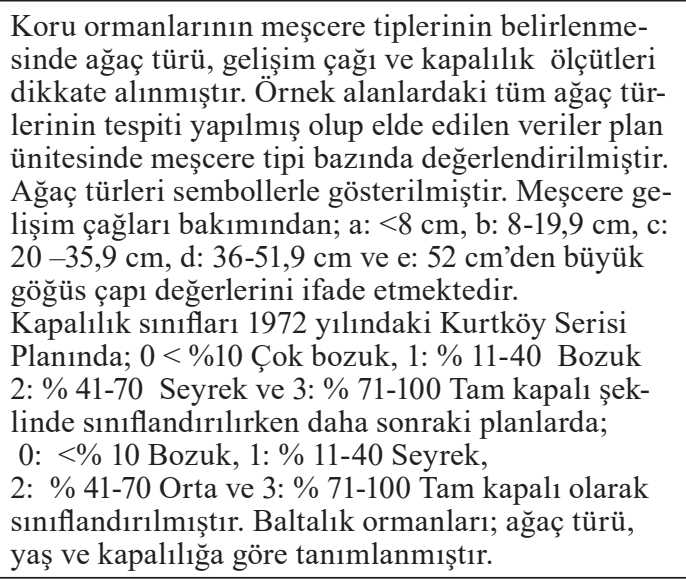 & $\begin{array}{l}\text { Plan ünitesinin } \\
\text { geneli için } \\
\text { İşletme silvi- } \\
\text { kültür planı } \\
\text { düzenlenmiştir. }\end{array}$ & $\begin{array}{l}\text { Koru orman- } \\
\text { larında bonitet } \\
\text { kayın için } \\
\text { üst boya göre } \\
\text { üç bonitet } \\
\text { sinıfı olarak } \\
\text { belirlenmiştir. } \\
\text { Bunlar; } \\
\text { 1- İyi bonitet, } \\
\text { 2- Orta bonitet } \\
\text { 3- Fena bonitet } \\
\text { şeklinde ta- } \\
\text { nımlanmıştır. }\end{array}$ \\
\hline $\begin{array}{l}\text { Yaş } \\
\text { Sinıfları } \\
\text { Metodu } \\
\text { (Ekosis- } \\
\text { tem Ta- } \\
\text { banli } \\
\text { Planlar) }\end{array}$ & $\begin{array}{l}\text { Çamdağ1 } \\
1917 \text { Orman } \\
\text { İşletme } \\
\text { Şefliği }\end{array}$ & $\begin{array}{l}\text { Koru ormanlarının meşcere tiplerinin belirlenme- } \\
\text { sinde ağaç türü, gelişim çağı ve kapalılık ölçütleri } \\
\text { dikkate alınmıştır. Klasik (Yaş Sınıfları) metoddan } \\
\text { farklı olarak } 0:<\% 10 \text { kapalılık sınıfı, bozuk ye- } \\
\text { rine boşluklu kapalı olarak tanımlanmıştır. Ayrıca } \\
\text { maki elemanları fonksiyonel verimlilik durumuna } \\
\text { göre değerlendirilmiştir. }\end{array}$ & $\begin{array}{l}\text { Plan ünitesinin } \\
\text { geneli için } \\
\text { İşletme silvi- } \\
\text { kültür planı } \\
\text { düzenlenmiştir. }\end{array}$ & $\begin{array}{l}\text { Bonitet ile il- } \\
\text { gili çalışmalar } \\
\text { yer almıştır. } \\
\text { Kayın ve meşe } \\
\text { beş bonitet } \\
\text { sinıfı olarak } \\
\text { planlanmıștır. }\end{array}$ \\
\hline
\end{tabular}




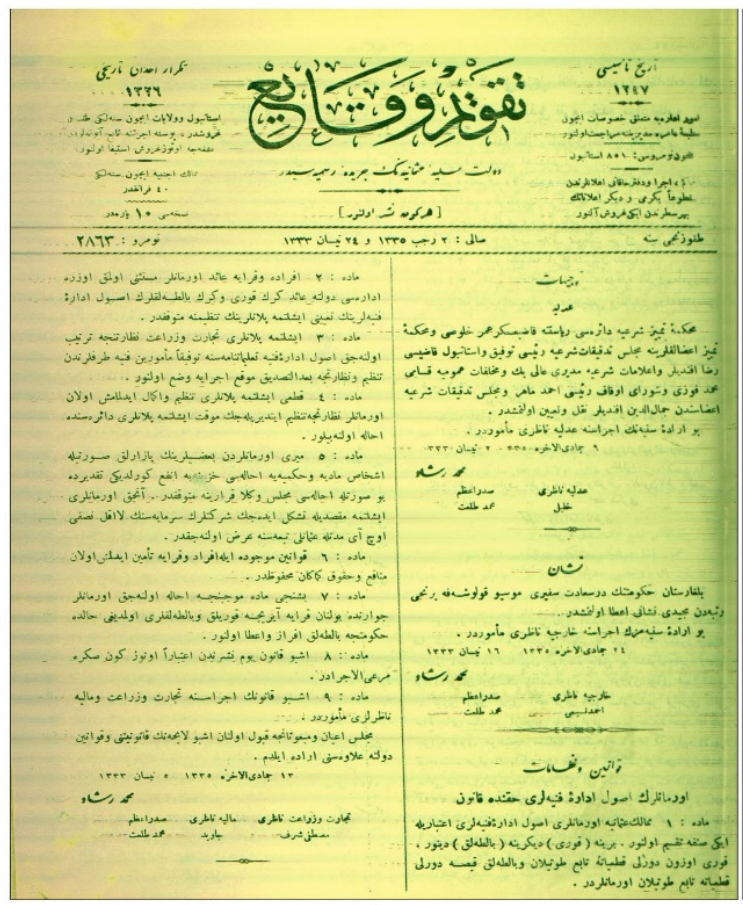

Takvim-i Vekâyi sayı: 2863

Yayın tarihi: 2 Receb 1335/24 Nisan 1333[24 Nisan 1917]

Ormanlarnn Usûl-i İdâre-i Fenniyeleri Hakkında Kânûn

Madde 1: Memâlik-i Osmâniye ormanları usûl-i idâre-i fenniyeleri i tibâriyle ik sinffa taksim olunur. Birine (koru) digerine (baltalık) denir. Koru, uzun devirli kat iyâta tâbi tutulan ve baltalik kısa devirli kat' iyâta tâbi tutulan ormanlardır.

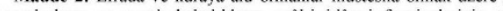
usûl-i idâre-i fenniyelerinin ta'yini, işletme Madde 3: İleme planlarn

Tirat Nezâretince tertib olunacak usîdâre-i fenniye tálimâtnâmesine tevfikan me'mûrìn-i fenniye taraflarndan tanzim ve Nezâretçe ba' de't-tasdîk mevki-i icrâya vaz' olunur. Madde 4: Kat' 1 işletme planlan tanzim ve ikmâl edilmiş olan orm zim ettirilecek muvakkat işletme planları dâiresinde ihale olunacaktir. Madde 5: Mîri ormanlardan bazılannın pazarlık sûretiyle eşhâs-1 mâddiyye ve
miyyeye ihâlesi Hazîne'ye enfa' görülduğü takdirde bu sûretle ihâlesi Meclis-i

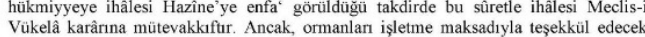
şirketlerin sermâyesinin lâ-akal nusfi üç ay müddetle Osmanlı tebe' asına arz olunacaktır. Madde 6: Kavânîn-i mevcûde ile efrâd ve kurâya te' mîn edilmiş olan menâfí ûk kemâ-kân mahfuzdur

Madde 7: Beșinci madde mûcebince ihâle olunacak ormanlar civârnnda bulunan kurâya aynca koruluk ve baltalikları olmadığı hâlde hükùmetçe baltalık ifrâz ve it crâdır.

adde 8: İşbu kânûn yevm-i neşrinden i'tibâren otuz gün sonra mer'iyyü'tMadde 9: İşbu kânûn icrâsna Ticâret ve Zirâat ve Mâliye Nezâretleri me'mûrdur. kabul olunan işbu lâyihann kââîn-i devlete ilâvesini irâde eyledim.

13 Cemayizelâhire 1335/5 Nisan 1333 [5 Nisan 1917]

Mehmed Reşad

Ticaret ve Ziraat Nâzırı

Mustafa Șeref

Mâliye Nâzırı

Sadrâzam
Mehmed Ta

Şekil 4. a) Osmanlı Türkçesi ile yazılmış Ormanların Usûl-i İdâre-i Fenniyeleri Hakkında Kânun, b) Kanunun bugünkü Türkçe'ye çevirisi

Figure 4. a) Turkey's first Forest Management Law/ Ormanların Usûl-i İdâre-i Fenniyeleri (Law no. 2863, Takvim-i Vekâyi (Official Gazetta) 24 April 1917) written in Ottoman Turkish, b) Translation of the Law into actual Turkish

Kurtköy Serisi Kat'i Amenajman Planı I. Revizyon (1969) planları 3116 SK kapsamında ve 1952 tarihli Orman Amenajman Planlarının Tanzimine ve Tatbikine Ait Talimatname esaslarına göre hazırlanmıștır. 1952 tarihli Orman Amenajman Yönetmeli$\breve{g} i$ ülke ormancılığının teknik gelişimine yetmediğ $i$ gerekçe gösterilerek bazı maddeleri 1955 yılında değiştirilmiştir.

1937 tarih ve 3116 sayıl Orman Kanunu (3116 SK), 1956 yilında 6831 sayılı Orman Kanunu (6831 SK) yürürlüğe girinceye kadar (19 yıl) yürürlükte kalmıştır.

Kurtköy Orman İşletme Şefliği Kurtköy Serisi Orman Amenajman Planı (1972), 6831 SK (26. madde) hükümlerine dayanılarak hazırlanmış ve 1955 tarihli Orman Amenajman Planlarının Tanzimine ve Tatbikine Ait Talimatname ile Arazi Envanter ve Harita İahnameleri' ne göre gerçekleştirilmiştir. 1973 yilında Orman Amenajman Planlarının Düzenlenmesine, Uygulanmasina ve Yenilenmesine Dair Yönetmelik ile Arazi Çalışmalarına Ait İzahname yürürlüğe girmiştir. $\mathrm{Bu}$ Amenajman Planı 1972-1991 yıllarını kapsayacak şekilde yürürlükte olduğundan, plan ünitesi için 1973 Yönetmeliğine göre yeni bir plan yapılmamıştır.

Kurtköy Orman İşletme Şefliği I. Yenileme (1994) ve Kurtköy Orman İşletme Şefliği II. Yenileme
(2004) planları 1991 tarihli Orman Amenajman Planlarının Düzenlenmesi, Uygulanmast, Denetlenmesi ve Yenilenmesi Hakkında Yönetmelik ile Arazi Çalışmalarına Ait İzahname esaslarına göre hazırlanmıştır.

Çamdağı 1917 Orman İşletme Şefliği'nin 2015 planı ise 2008 tarihli Orman Amenajman Yönetmeliği ile 2014 tarih ve 299 sayıl Ekosistem Tabanlı Fonksiyonel Orman Amenajman Planlarının Düzenlenmesine Ait Usul ve Esaslar Tebliği'ne göre gerçekleştirilmiştir. Tebliğ geçmiş dönemlerde Arazi Teknik İzahnamesi ve Harita Çizim İzahnamesi şeklinde hazırlanan mevzuatı da kapsamaktadır.

\subsection{Haritaların oluşturulması ve envanter}

Türkiye'de ilk olan bu planlama ünitesinde, 1917'den 2015'e kadarki sekiz plan döneminde meydana gelen alan değişiklikleri Şekil 5'te verilmiştir. İlk adıyla Hendek Mustafa Şeref Bey Ormanı 1917 yılında 7.197,04 ha iken, Çamdağ Serisi I. Devre Amenajman Planı (1946), sınırlarının değişmesiyle alanı \%105,8 artarak 14.810,0 ha'a çıkmıştır.

Üçüncü dönemde Kurtköy Serisi Kat'i Amenajman Planı (1955) adıyla planlanmış, sınırları değiştirilmiş ve alanı 8.511,75 ha olmuştur. Dördüncü dönemde Kurtköy Serisi Kat’i Amenajman Planı I. 


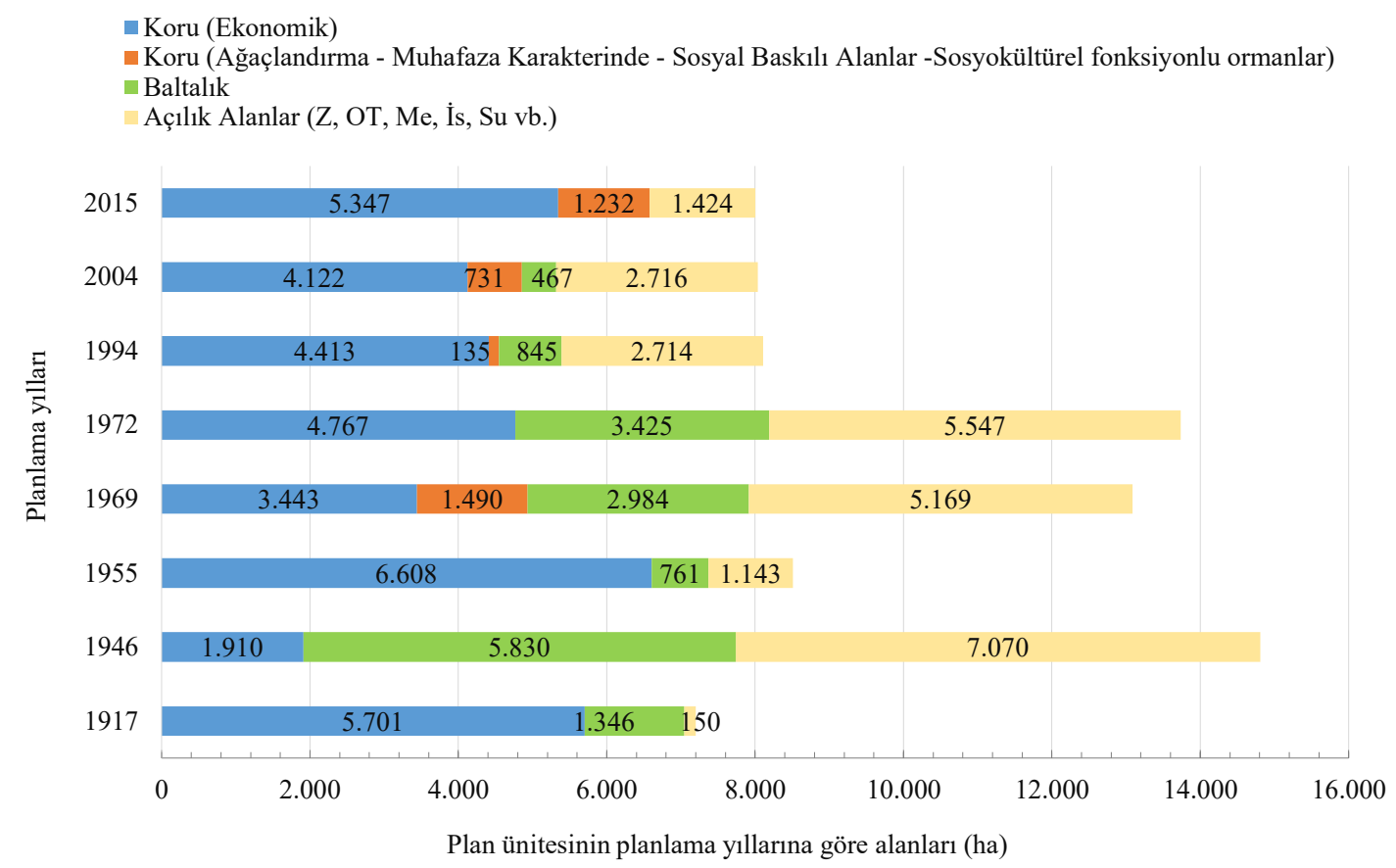

Şekil 5. 1917-2015 dönemindeki planlarda orman işletme şekillerinin ve açıklık alanların dağılımı Figure 5. Proportional distribution of working circles types and open areas in management plans between1917-2015

Revizyon (1969) adıyla planlanmış, sınırlarında önemli değişiklikler yapılmış ve alanı 13.086,0 ha olmuştur. Beşinci dönemdeki adıyla Kurtköy Orman İşletme Şefliği Kurtköy Serisi Orman Amenajman Planı'nın (1972) sınırlarında ve alanında dördüncü ve daha önceki dönemlere kıyasla çok büyük değişiklikler olmamış ve tüm alanı 13.739,0 ha olmuştur. Plan ünitesinin alanı, Kurtköy Orman İşletme Şefliği I. Yenileme (1994) planında 8.105,5 ha, yedinci plan dönemindeki adıyla Kurtköy Orman İşletme Şefliği II. Yenileme (2004) planında ise 8.036,4 ha olarak görülmektedir. Bu iki dönemde de hem plan ünitesinin sınırlarında hem de alanında değişiklikler gerçekleşmiştir.

Son dönemde plan ünitesinin adı ilk planın yapıldığ 1 yeri ve tarihi kapsayacak şekilde değiştirilmiş, sinırları ve alanı 1917 yılındaki sınırlarla olabildiğince örtüşecek şekilde planlanmış ve böylece Çamdağı 1917 Orman İşletme Şefliği’nin (2015) toplam alanı 8.002,1 ha olarak belirlenmiştir.

Hendek Mustafa Şeref Bey Ormanı'nın ilk orman planlama çalışmalarında, alana ait harita altlığı olmadığı için 1916 yılında öncelikli olarak plan ünitesinin 1/10.000 ölçekli nirengi ağ sistemi kurulmuş ve bundan yararlanılarak 1/20.000 ölçekli iç taksimat ve orman haritası oluşturulmuştur.

İşletmeye açılacak veya çalışmakta bulunan ormanların odun varlıklarını ve alanlarını yaklaşık olarak belirleme işi İstikşaf Planlar ile yapılmıştır
(OGM, 1954; Şahin, 2020). Çamdağ Serisi I. Devre Amenajman Planı (1946) istikşafı plan olarak hazırlanmış ve harita altlığ 1 olarak Harita Genel Müdürlüğü (HGM, harita.gov.tr) tarafından üretilen 1/200.000 ölçekli istikşafı haritalar kullanılmıştır.

İstikşaf sonucunda işletmeye açılması öngörülen veya işletilen ormanların harita ve planlarını düzenleme, uygulanacak işletme şekillerini, ağaç türü ve serveti ile yıllık verimlerini ayrıntılı inceleme ve hesaplama işleri ise Kat'i Amenajman Planları ile gerçekleştirilmiştir (OGM, 1954; Şahin, 2020). HGM tarafından üretilen 1/25.000 ölçekli topografik memleket paftaları, bu plan ünitesinde ilk kez Kurtköy Serisi Kat'i Amenajman Planı'nın (1955) yapımında kullanılmıştır. Ülkemizdeki her türlü ormancılık çalışmalarında kullanılan meşcere haritalarının yapılmasında 1/25.000 ölçekli topografik memleket paftaları altlık olarak kullanıldığ 1 için 1969, 1972, 1994, 2004 ve 2015 yıllarında da plan ünitesi ormanlarına ait haritanın yapılmasında bu paftalardan yararlanılmıştır.

Meşcere (orman) haritaları 2004 yılına kadar aydınger üzerine elle çizilerek; Kurtköy Orman İşletme Şefliği II. Yenileme (2004) planı meşcere haritası ise ilk defa sayısal olarak Netcad programıla üretilmiştir. Çamdağı 1917 Orman İşletme Şefliği planının harita düzenleme işleri bilgisayar ortamında ArcGIS programı kullanılarak gerçekleştirilmiştir. Plan tablolarının elde edilmesi ile planın yapımında App yazılımı kullanılmıştır. Her iki 
plan dönemi iç taksimatlandırma çalışmalarında, rektifikasyon işlemi yapılmış olan 1/25.000 ölçekli topografik paftalardan da yararlanılmıştır.

Kurtköy Orman İşletme Şefliği Kurtköy Serisi Orman Amenajman Planı (1972) çalışmalarında ilk kez siyah-beyaz hava fotoğrafları, Kurtköy Orman İşletme Şefliği I. Yenileme (1994) çalışmalarıyla da ilk defa renkli kızılötesi hava fotoğrafları kullanılmaya başlanmıştır. 2004 planlama çalışmalarında renkli kızılötesi hava fotoğrafları, 2015 yılında ise Quickbird uydu görüntüleri kullanılmıştır.

Planlama ünitesi birimi olarak ilk planlama çalışmasında bölme ve bölmecik kullanılmış; Çamdağ Serisi I. Devre Amenajman Planı (1946) ise istikşaf1 yöntemle havza bazında planlanmıştır. Kurtköy Serisi Kat'i Amenajman Planı (1955) ile Kurtköy Serisi Kat'i Amenajman Planı I. Revizyon (1969) planlarında, planlama ünitesi birimi olarak ilk planlama çalışmasında olduğu gibi yeniden bölme ve bölmecik dikkate alınmıştır. Kurtköy Orman İşletme Şefliği Kurtköy Serisi Orman Amenajman Planı (1972) ile birlikte meşcere tipi kavramı, meşcere haritalarının ve planlama çalışmalarının önemli bir ögesi haline gelmiştir. Planlama ünitesi birimi olarak bölmelerin yanı sıra meşcere tipleri de taksimatlandırmada etkin bir şekilde kullanılmaya başlanmıştır. 1994, 2004 ve 2015 yıllarında da planlama ünitesi birimi olarak bölme ve meşcere tipi kullanılmaya devam etmiştir.

Örnekleme yöntemi, 1917 planında bölmecik alan değerlendirmesi şeklinde yapılırken, 1946 planlama çalışmalarında havza içerisinde istikşafı ve tecrübe şeritleri yöntemi, 1955 ve 1969 Kat'i amenajman planlarının yapımında ise bölme içerisinde tecrübe şeritleri yöntemi biçiminde gerçekleştirilmiştir. Kurtköy Orman İşletme Şefliği Kurtköy Serisi Orman Amenajman Planı (1972) ile plan ünitesinde, koru ormanları için sistematik örnekleme yöntemleri (500x500 m) kullanılmaya başlanmıştır. Kurtköy Orman İşletme Şefliği I. yenileme ve II. yenileme planlarında örnek alanların belirlenmesi için verimli koru ormanlarında 300x300 $\mathrm{m}$ aralık ve mesafelerle sistematik örnekleme yöntemi kullanılmıştır. 2015 planlamalarında ise \%1040 kapalı meşcereler ile ekolojik ve sosyokültürel fonksiyonlu orman alanları olarak ayrilan alanlara 600x600 m; kapalılığ1 \%40'dan yüksek olan ve ekonomik fonksiyonlu olarak ayrilan orman alanlarında örnek alanlar 300×300 m aralık ve mesafelerle sistematik olarak dağıtılmıştır.

Örneklem şekli ve büyüklüğü, ilk planlama çalışmasında her bölme ve bölmecik ile ilgili alansal bilgi toplama şeklinde gerçekleştirilirken, 1946 planlamasında havzayı baştan sona kat eden hat üzerinde, 1955 ve 1969 planlama çalışmalarında ise bölme içerisinde alınan $20 \mathrm{~m}$ genişliğindeki tecrübe şeritlerinde veriler elde edilmiştir. 1972 yılında hazırlanan plan ile örneklem sayısı, şekli ve büyüklüğü belirli standartlara kavuşturulmuştur. Örneklemin şeklinin daire, büyüklüğünün ise ormanın verimlilik ve kapalılık durumuna göre $400 \mathrm{~m}^{2}, 600 \mathrm{~m}^{2}$ ve $800 \mathrm{~m}^{2}$ olması kararı verilmiştir. 1972 plan dönemiyle birlikte orman planlamaya kazandırılan bu yöntemler, bazı küçük değişikliklerle birlikte 1994, 2004 ve 2015 planlama çalışmaları için de geçerliliğini korumuştur.

\subsection{Planlama ilkeleri ve faydalanmanın düzenlenmesi}

Hendek Mustafa Şeref Bey Ormanı (1917), Türkiye'nin ilk orman amenajman planı olmasının yanında, yaş sınıfları yönteminin eşit yaşlı ormanları düzenlemeye yönelik de ilk uygulamasıdır. Plan ünitesi ormanları 1946, 1955 ve 1969 yıllarında çap sınıfları metoduna göre planlanmış; 1972 planında ise Kurtköy Serisi ormanlarında, ikinci kez amenajman metodu olarak yaş sınıfları metoduna geçilmiştir. Plan ünitesi ormanları 1972 yılından itibaren yaş sınıfları yöntemiyle planlanmaktadır.

\subsubsection{Hendek Mustafa Şeref Bey Ormanı (1917)}

Koru ve baltalık ormanları için odun üretimi amaçlarını gerçekleştirmek ve yapısı çeşitli nedenlerle bozulmuş olan meşcereleri koruma, ağaçlandırma ve rehabilitasyon yöntemleriyle iyileştirmek amacıyla planlanmıştır. Koru işletme sınıfının amaç kuruluşu; plansız müdahalelerle bünyesi bozulan koru ormanlarını ıslah ve imar etmek, yetişme ortamının elverdiği en yüksek miktar ve kalitedeki hasılatı (odun ürününü) devamlı olarak almak şeklinde belirtilmiştir. Baltalık işletme sınıfının plandaki amaç kuruluşu ise meşcere içerisindeki boşlukları doldurmak, düzensiz baltalık ve korulu baltalık görünümündeki meşcereleri düzenli hale sokmak ve yetişme ortamının elverdiği en yüksek miktardaki hasılatı devamlı olarak elde etmek şeklinde açıklanmıştır. Koru ormanları için idare süresi 120 yıl ve yakacak odunu elde edilecek baltalık ormanları için 20 yıl olarak belirlenmiştir.

Amenajman planında meşcere gelişim çağlarını ifade edebilecek sembol ve ölçütler bulunmamaktadır ve bölmecikler harf sembolleriyle gösterilmiştir. Plandaki tüm meşcerelerde yapılacak kesimlerle ilgili bilgiler Kat'iyyât (kesim), ağaçlandırma ve ekim çalışmaları ile ilgili açıklamalar ve öneriler ise Kültür (teşcir) planı kısmında genel esaslarıyla verilmiş; her bölmecik için hangi silvikültürel uygulamaların yapılması gerektiği de önerilmiştir. Silvikültürel işlem ünitesi olan bölmeciklerde, 
farklı fonksiyonları da dikkate alan silvikültürel uygulamaların önerildiği görülmektedir. Özellikle orman üzerindeki sosyal baskıyı azaltacak ve ormanın sürekliliğini sağlayacak öneriler neredeyse her bölmecik için ayrı ayrı belirtilmiştir.

Planda her bölme ya da bölmecik ayrı bir işlem ünitesi olarak tanımlandığı için, her işlem ünitesi için ağaç türleri ile ağaç türlerinin karışım oranları, plandaki tabloların tahlil ve tavsif bölümlerinde verilmiştir. Ağaç serveti kapsamında değerlendirilmeyen ve meşcerede serpili bulunan ağaç türleri de her bölmecik için ayrı ayrı plan tablolarında tarif edilmiştir. Mevkii, toprak ve bazı iklim elemanları ile yetişme ortamı faktörlerine ait bilgiler ormanın bütünü ve her bölmecik için ayrı ayrı toplanmıştır. Yetişme ortamı hakkındaki veriler, planda meşcerelerin tahlil ve tavsifinin verildiği tablolarda her bölmecik için ayrıntılı olarak açıklanmıştır. Meşcerenin yaşı ile orta boyu ölçülerek bölmenin azami ve asgari bonitet değerleri belirlenmiş, bunlardan da yararlanarak meşcere orta boyuna göre meşcerenin bonitet sinıfı tayin edilmiştir. Bonitet tayini için Feissmantel ve Pressler'in bonitet tabloları kullanılmıştır. Meşcere kapalılıği (kesafet), planda 0 ile 1 değerleri arasında ve 0,1 hassasiyetiyle 10 kategori oluşturacak şekilde belirtilmiştir. Verimli koru ve baltalık ormanları için belirlenen meşcere kesafeti sadece kapalılık ölçütüne göre, aynı zamanda meşcere sıklığını da dikkate alacak şekilde belirlenmiştir. Plan ünitesinde verimli orman alanının $\% 65,85$ ' $\mathrm{i}$ 0,5-0,3 ve $\% 33,66$ 's1 0,8-0,6 kesafet derecesine sahiptir. Plan alanının \%63,84'ü kayın ve kayınla karışık, \%29,12'ü ise meşe ve meşe ile karışık meşcerelerdir (OGM, 1917b).

\subsection{2 Çamdağ Serisi I. Devre Amenajman Planı (1946)}

İstikşafı yöntemle yapılan orman amenajman planında işletme sınıfı kavramı yer almamış, ancak, ormanlar koru ve baltalık olarak iki işletme s1nıfında planlanmış; işletme amaçları ise açıkça tanımlanmamıştır. Ancak sözel bilgilerden, baltal1k ormanlarından maden direği ve yakacak odunun, koru ormanlarından ise yapacak emvalin elde edilmesinin amaçlandığı anlaşılmaktadır. Çap s1nıfları metoduna göre planlanmış ormanlarda seçme kesimleri uygulanmış, koru ormanları için idare süresi ve amaç çapı belirlenmemiştir. Baltalık işletme sınıfında idare süresi, yakacak odun için 30 yıl ve maden direği için 36 yıl belirlenmiştir. Planda meşcere tipi ve meşcere gelişim çağı ile ilgili kavramlar bulunmamakta; kapalılık havza bazında ve "ondalık” düzeyinde tanımlanmıştır. Ağaç türü ile ilgili kısa bilgiler verilmiştir. Toprak özellikleri, diri örtü ve ölü örtü gibi bilgiler havzaya ait olarak verilmiş; bonitet ile ilgili çalışmalara ise planda yer verilmemiştir (OGM, 1946b).

\subsubsection{Kurtköy Serisi Kat'i Amenajman Planı (1955)}

Koru ve baltalık olmak üzere iki işletme sınıfına ayrılmıştır. Koru ormanları, korumaya ayrılanlar ve temizleme kesimi yapılacak bölmeler şeklindedir. İki işletme sınıfı da üretim ormanı olarak planlanmış olsa da plandaki koru ormanlarında, koruma amaçlı alanlar belirlenmiş ve bu alanlarda silvikültürel müdahale öngörülmemiştir. Baltalık orman alanlarında ilk defa kesim düzenleri oluşturulmuştur. Koru ormanları en yüksek odun hasılatı, baltalık ormanları ise yakacak odun üretme amaçlarını yerine getirmek için planlanmıştır. Koru ormanları çap sınıfları metoduna göre planlanmış, koru ve baltalık ormanları için amaç çapı ile birlikte idare süreleri de saptanmıştır. Koru ormanlarında idare süresi kayın için 150 yıl ve meşe için 200 yıl, amaç çapı ise kayın için $57 \mathrm{~cm}$ ve meşe için $78 \mathrm{~cm}$ olarak saptanmıştır. Baltalık ormanları için idare süresi 30 yıl ve amaç çapı $12-14 \mathrm{~cm}$ olarak belirlenmiş ve seçme kesimleri uygulanmıştır.

Planda bölmecikler harf sembolleriyle gösterilmiş; her bölmecik için meşcere orta yaşı ve kapalılık tespit edilmiştir. Meşcere gelişim çağı ile ilgili kavramlar ise bulunmamaktadır. Silvikültürel durum ifadeleri her bölmecik/meşcere için ayrı ayrı tanımlanmıştır. Ağaç türleri ya da cinslerinin bölmecik içerisindeki oransal dağılımı ve meşcere sıklığ 1 hakkında bilgiler "meşcerenin tavsifi ve işletme planı" cetvelinin ilgili sütunlarında yer almıştır. Koru ormanlarında ağaç türlerinin \%69’u kayın, \%28'i meşe, \%3'ü ise göknar, ıhlamur, kavak ve kestanedir. Baltalık ormanlarında asli türler meşe, kayın ve gürgendir. Kapalılık 0,1-1,0 arası ondalık düzeyde saptanmıştır ve meşcerelerin kapalılığ korularda 0,4-0,8 arasında belirlenmiştir. Toprak özellikleri, diri örtü ve ölü örtü gibi bilgiler bölme ya da bölmecikler bazında verilmiş, ancak bonitet ile ilgili çalışmalara planda yer verilmemiştir (OGM, 1955b).

\subsubsection{Kurtköy Serisi Kat'i Amenajman Planı I. Revizyon (1969)}

Koru, baltalık ve ağaçlama olarak üç işletme sınıfına ayrılmıştır. Koru ormanlarının işletme amacı en yüksek hasılat, baltalık ormanlarının işletme amacı yakacak odun elde etmek, ağaçlama işletme sınıfının işletme amacı ise belirlenen sürede ve planlar dahilinde bozuk ormanları verimli ormanlara dönüştürmektir. Ormanlar çap sınıfları metoduna göre planlanmış olmasına rağmen, ağaç 
türlerinin belirlenmiş hedef amaç çapına ulaşması için gerekli olan süre dikkate alınarak, ağaç türleri için idare süreleri de saptanmıştır. Faydalanmalar seçme kesimleri ile gerçekleştirilmiştir. Koru ormanlarında idare süresi kayın için 120 yıl ve meşe için 200 yıl, Baltalık ormanları için idare süresi 20 yıl belirlenmiştir.

Planda bölmecikler harf sembolleriyle gösterilmiş, her bölmecik için meşcere orta yaşı ve kapalılık tespiti yapılmıştır. Meşcere tipi ve gelişim çağı ile ilgili kavramlar ise yoktur. Silvikültürel durum ifadeleri her bölmecik/meşcere için ayrı ayrı tanımlanmıştır. Ağaç türleri ya da cinslerinin bölmecikteki oransal dağılımı ve meşcere sıklığı hakkındaki bilgiler "meşcerenin tavsifi ve işletme planı" cetvelindedir. Koru ormanlarının \%77,7'si kayın, $\% 15,1$ 'i meşe, $\% 6,2$ 'si gürgen ve $\% 1$ 'i ise 1 hlamur, kavak, kestane, göknar, karaağaç ve kızılağaçtır. Baltalık ormanlarının \%49'u kayın, \%42'si meşe, \%6'sı gürgen ve \%3'ü ise kavaktır. Meşcere kapal1lığ 1 0,1-1,0 arasında ondalık düzeyinde saptanmış, koru meşcerelerinin kapalılıkları 0,2 ile 0,9 arasında belirlenmiştir. Bir önceki Kat'i plan döneminde olduğu gibi, toprak özellikleri, diri örtü, ölü örtü gibi bilgiler bölme ya da bölmecikler bazında verilmiş, ancak bonitet ile ilgili çalışmalar planda verilmemiştir (OGM, 1969).

\subsubsection{Kurtköy Orman İşletme Şefliği Kurtköy Serisi Orman Amenajman Planı (1972)}

Kayın İşletme Sınıfı (Koru) ve Baltalık İşletme Sınıfı olmak üzere iki işletme sınıfına ayrılmıştır. Koru ormanının işletme amacı en yüksek odun hasılatı, baltalık ormanının işletme amacı ise en yüksek miktarda yakacak odun hasılatı elde etmektir. Plan ünitesi koru ormanları yaş sınıfları metoduna, baltalık ormanları eşit yıllık alan tıraşlama metoduna göre planlanmıştır. Ormanlar yaş sınıfları metoduna göre planlanmış olmasına rağmen, ağaç türleri için hedef çapları da belirlenmiştir. Koru ormanlarında orta çap $45 \mathrm{~cm}$, baltalık ormanlarında ise $6 \mathrm{~cm}$ olarak kararlaştırılmıştır. Ağaç türleri için idare süreleri saptanırken bonitet sınıfları da dikkate alınmıştır. Koru ormanlarında kayın için idare süreleri iyi bonitette 90 yıl, orta bonitette 110 yıl ve fena bonitette 125 yıl, Baltalık ormanları için idare süresi plan ünitesinin geneli için 20 yıldır

Yaş sınıfları metodunun kullanılmasıyla ağaç türü, meşcere gelişim çağı, kapalılık ve meşcere tipi ile ilgili bilgiler planda ayrıntılı verilmiştir. Arazi envanter çalışmalarında ağaç türü, meşcere gelişim çağı ve kapalılık ile ilgili bilgiler sistematik örnek alanlarından ayrıntılı toplanmıştır. Meşcere tipi kavramı ilk defa ağaç türü, çağ sınıfı (gelişim çağı) ve kapalılık parametreleri birlikte bütünleşik halde bölmecikleri tanımlamak amacıyla kullanılmıştır. Örnek alanlardaki tüm ağaç türleri tespit edilmiş ve bu veriler plan ünitesinde meşcere tipi bazında değerlendirilmişstir. Ağaç türleri sembollerle gösterilmiştir.

Meşcere gelişim çağları; göğüs çapı a: $<8 \mathrm{~cm}$; b: 8-19,9 cm; c: $20-35,9 \mathrm{~cm}$; d: $36-51,9 \mathrm{~cm}$ ve e: 52 cm'den büyük olacak şekilde sınıflandırılmıştır. Meşcere kapalılığ 1 ise $0<10$ Çok bozuk, 1: \%11-40 Bozuk, 2: \%41-70 Seyrek ve 3: \%71-100 tam kapalı şeklinde sınıflandırılmıştır. Verimli baltalık ormanlarının meşcere tiplerini belirlemede kapalılık ve birim alandaki hacimleri de dikkate alınarak iyi, orta ve zayıf baltalık şeklinde gruplandırılmışlardır.

Plan dönemiyle birlikte meşcere yaşının tespiti, planlama yönteminin değişmesiyle oldukça önem kazanmış ve her örnek alanda meşcerenin asli ağaç türünün ortalama yaşı esas alınarak yaş tespiti yapılmıştır. Bu dönem plan ünitesi ormanlarının \%60,49'u kayın ve kayınla karışık, \%39,51'i ise meşe ve meşe ile karışık meşcerelerdir. Silvikültürel durum ifadeleri plan ünitesinin genelini kapsayacak şekilde her meşcere tipi için ayrı ayrı tanımlanmış ve plan ünitesinin geneli için İşletme Silvikültür Planı düzenlenmiştir.

Yetişme ortamı envanteri yapılmamış, ancak plan ünitesinin geneli için arazinin jeolojik ve mineralojik yapısı ile ilgili ayrıntılı bilgiler toplu halde verilmiştir. Yetişme ortamının verim gücünü belirlemek için koru ormanlarında bonitet tespitleri yapılmış ve plan ekinde meşcere haritası ile birlikte bonitet haritası da verilmiştir. Koru ormanlarında kayın için üst boya göre üç bonitet sınıfı belirlenmiş ve 1- İyi bonitet, 2- Orta bonitet ve 3- Fena bonitet şeklinde tanımlanmıştır.

1972 plan dönemiyle birlikte orman planlama çalışmalarında yaş sınıfları orman amenajman metodunun unsurları olarak öne çıkan değişkenler, bazı küçük değişikliklerle 1994, 2004 ve 2015 planlamaları için de geçerlidir. Kurtköy Orman İşletme Şefliği Kurtköy Serisi Amenajman Planı (1972) ile ortaya konulan kavramlar ve faydalanmayı düzenleme esasları 1994, 2004 ve 2015 planları için de geçerliliğini koruduğu için o dönemlerde sadece meydana gelen farklılıklar ve değişiklikler aşağıda verilmiştir (OGM, 1972).

\subsubsection{Kurtköy Orman İşletme Şefliği I. Yenileme (1994)}

Plan ünitesi ormanları, Kayın (Koru), Baltalık ve Muhafaza Karakterinde İşletme Sınıfları olarak planlanmıştır. Koru üretim ormanlarının işletme amaçları açıkça tanımlanmamış; meşcere yapısı bozulmuş ve sosyal baskılı ormanlar ise muhafaza 
karakterinde planlanmıştır. Planda koru ormanları yaş sınıfları metoduna, baltalık ormanları ise eşit yıllık alan tıraşlama metoduna göre planlanmıştır. Yaş sınıfları orman amenajman metodunun unsurları olarak öne çıkan değişkenlerden ağaç türü, meşcere gelişim çağ 1 ve kapalılık ile ilgili bilgiler planın meşcere tipleri tanıtım tablosunda verilmiştir. Ağaç türleri için idare süreleri ortalama bonitet dikkate alınarak kararlaştırılmış ve kayın için idare süresi 120 yıldır. Baltalık ormanları için idare süresi plan ünitesinin geneli için 20 yıldır. Baltalık ormanları ağaç türü, yaş ve kapalılığa göre sembollendirilmiştir.

Meşcere gelişim çağları önceki plan dönemindeki standartlar ile sınıflandırılırken, meşcere kapalılığ ise 0: $<\% 10$ Bozuk, 1: \%11-40 Seyrek, 2: \%41-70 Orta ve 3: \%71-100 Tam kapalı olarak sinıfland1rılmıştır. Silvikültürel işlerin düzenlenmesi, plan ünitesinin geneli için İşletme Silvikültür Planı başlığıyla verilmiştir. Gençleştirilecek alanlar için Orman Genel Müdürlüğü (OGM), Silvikültür Dairesi Başkanlığı'nın sorumluluğunda olacak şekilde Silvikültür Planı düzenlenmiştir. Yetişme ortamı envanteri yapılmamış, plan ünitesinin geneli için arazinin jeolojik ve mineralojik yapısı ile ilgili bilgiler önceki plandan alınmış, ya da alana ilişkin literatür bilgileri plana ek olarak verilmiştir. Yetişme ortamının verim gücünü belirlemek için koru ormanlarında bonitet tespitleri yapılmamış ve bu veriler önceki plandan alınmıştır. Orman amenajman planına ek olarak meşcere haritası, bonitet haritası ve bunlara ek olarak yaş sınıfları haritası konulmuştur (OGM, 1994).

\subsubsection{Kurtköy Orman İşletme Şefliği II. Yenileme (2004)}

Plan ünitesi ormanları sekiz işletme sınıfı altında planlanmış; altısı ekonomik, ikisi ise ekolojik fonksiyonlu ormanlar olarak ayrılmıştır. Ekonomik fonksiyonlu koru ormanlarının işletme amacı en yüksek odun hasılatı, baltalık ormanının işletme amacı ise en yüksek miktarda yakacak odun elde etmektir. Ekolojik fonksiyonlu işletme sınıfları ayrılırken, hem doğrudan ormanların usulsüz faydalanmalardan korunmasını hem de ormanların koruyucu etkisini dikkate alan işletme amaçları ve koruma hedefleri dikkate alınmıştır.

Önceki plan dönemlerinden farklı olarak, ağaçlandırma yoluyla elde edilmiş karaçam meşcereleri ile hızlı gelişen tür ağaçlandırmalarıyla oluşturulan sahilçamı + yalancı akasya meşcereleri için en yüksek miktarda odun üretimi amaçlı işletme sınıfı oluşturulmuştur. Koru ormanları yaş sınıfları metoduna, baltalık ormanlar ise eşit yıllık alan tıraşlama metoduna göre planlanmıştır.
Yaş sınıfları metodunun unsurları olarak öne çıkan değişkenlerden ağaç türü, meşcere gelişim çağ1 ve kapalılık ile ilgili bilgilere meşcere tipleri tanıtım tablosunda verilmiştir.

Ağaç türleri için idare süreleri ortalama bonitet dikkate alınarak kararlaştırılmış; ekonomik fonksiyonlu ormanların ağaç türleri için kayında 160 yıl, meşede 200 yıl, karaçamda 100 yıl ve sahilçamında 40 yıl olarak belirlenmiştir. Meşe koruya tahvil (dönüştürme) süresi 80 yıl, baltalık ormanları için idare süresi 20 yıl, ekolojik fonksiyonlu Toprak Koruma İşletme Sınıfı'ndaki ormanlar için idare süresi ise 320 yıl olarak kararlaştırılmıştır. Koru ormanlarında meşcere gelişim çağları ve meşcere kapalılık sınıfları önceki planda olduğu gibi uygulanmıştır. Baltalık ormanları önceki planda olduğu gibi ağaç türü, yaş ve kapalılığa göre sembollendirilmiştir. Silvikültürel işleri düzeleme ve silvikültür planı yapma esasları da önceki plandaki olduğu gibi gerçekleşmiştir. Yetişme ortamının verim gücünü belirlemek için koru ormanlarında bonitet tespitleri yapılmamış ve veriler önceki plandan alınmıştır. Ağaçlandırmayla elde edilen ibreli türlere ait meşcerelerin orta yaşı saptanmış, geniş yapraklı türlere ait meşcerelerin orta yaşları ise önceki plandan alınmıştır (OGM, 2004).

\subsection{8. Çamdağı 1917 Orman İşletme Şefliği (2015)}

Önceki plan döneminde olduğu gibi, ormanlar sekiz işletme sınıfı altında planlanmış olup dördü ekonomik, üçü ekolojik ve biri sosyokültürel fonksiyonlu ormanlardır. Ekonomik fonksiyonlu üç işletme sınıfında işletme amacı en yüksek miktar odun üretimi iken, diğer işletme sınıfının amacı odun dışı ürün elde etmektir. Ekolojik fonksiyonlu ormanlar toprak ve su erozyonunu önlemek, usulsüz faydalanmaların olduğu meşcereleri iyileştirip korumak, ormandan işgal edilmiş ve fındık alanlarına dönüştürülmüş, ama hukuken orman vasfına sahip alanların konumlarını belirlemek için üç ayrı işletme sınıfı olarak planlanmıştır. Sosyokültürel fonksiyonlu ormanlar rekreasyon işletme amacını yerine getirmek üzere planlanmıştır. Plan baltalık ormanları 2006 yılından sonra koru işletme sınıflarına aktarıldığı için ormanların tümü koru olarak planlanmıştır. Yaş sınıfları orman amenajman metodunun unsurları olarak öne çıkan meşcere tipini sembollendirmede kullanılan ağaç türü, meşcere gelişim çağı ve kapalılık ile ilgili bilgiler plandaki meşcere tipleri tanıtım tablolarında verilmiştir.

Ekonomik fonksiyonlu ormanlarda ağaç türleri için idare süreleri ortalama bonitet dikkate alınarak kararlaştırılmış; ekolojik ve sosyokültürel fonksiyonlu ormanlarda ise ağaç türü ile birlikte işletme 
sınıfının koruma hedefleri de dikkate alınmıştır. İdare süreleri, ekonomik fonksiyonlu ormanların ağaç türleri için karaçamda 100 yıl, kayında 140 yıl, meşede 100 yıl ve yalancı akasya + kestanede (ODOÜ- odun dışı orman ürünü) 100 yıl olarak belirlenmiştir. Ekolojik fonksiyonlu ormanlardan meşe + kayın (Sosyal baskılı alanlar) 100 yıl, fındık (Sosyal baskılı alanlar) 100 yıl ve kayın (Toprak koruma ve erozyonu önleme) için idare süresi 160 yıldır. Sosyokültürel fonksiyonlu ormanlar rekreasyon işletme amacı ile planlanmış Kayın + Meşe İşletme Sınıfı olup idare süresi 160 yıldır.

Koru ormanlarında meşcere gelişim çağları önceki plandaki gibi uygulanmış, meşcere kapalılık sınıfında ise önceki planda "bozuk kapalı" tanımlanan ormanlar 299 sayılı Tebliğ hükümlerine göre "boşluklu kapalı" olarak değiştirilmiştir. Arazi envanter çalışmalarında ağaç türü, meşcere gelişim çağ ve kapalılık ile ilgili bilgiler örnek alanlardan ayrıntılı toplanmıştır. Çamdağı 1917 Orman İşletme Şefliği (2015) planında alanın \%69,32'si kayın ve kayınla karışı meşcereler, \%20,65'i meşe ve meşe ile karışık meşcereler, \%7,02'si ise karaçam ve karaçam ile karışık meşcerelerdir.

Planda yetişme ortamının özellikleri ile ilgili bilgiler verilmiş, bölgenin jeoloji haritası ile meteorolojik verileri plana konulmuş ve iklim değişkenleri ayrıntılı açıklanmıştır. Yetişme ortamının verim gücünü belirlemek için bonitet tespiti yapılmamıştır. Kayın için önceki planlarda kullanılan üç bonitet sınıfi, bu planda beş bonitet sınıfı olarak kullanılmıştır. Meşcerelerin ortalama yaşları önceki plandan alınmış, örnek alanlarda yaş tespiti yapılmamıştır. Bakım alanlarındaki eta belirlenirken, her meşcere tipi için meşcerenin hektardaki serveti, artımı ve taksasyon sonucu belirlenen silvikültürel eta miktarından yararlanılmıştır. Bakım bloklarının oluşturulması ve uygulama zamanı (zaman-mekân düzeni) uygulamacıya bırakılmıştır (OGM, 2015).

\section{Tartıșma ve Sonuc}

Çalışmada, 1917 yılındaki adıyla Hendek Mustafa Şeref Bey Ormanı, günümüzdeki adıyla Çamdă̆ 1917 Orman İşletme Şefliği planlama ünitesi özelinde, ülkemizde ilk orman amenajman planının yapıldığ 1917 yılından, son amenajman planının yapıldığı 2015 yılına kadarki zamanda, orman amenajmanının geçirdiği teknik ve yapısal süreçler zamana bağlı olarak incelenmiştir. $\mathrm{Bu}$ yıllar arasında sekiz kez planlama yapılmış, bu planlar ve haritalar ile planların dayanaklarını oluşturan mevzuattan yararlanarak, orman amenajmanın yaklaşık yüzyıllık sürede geçirdiği teknik ve yapısal değişiklikler aşağıda tartışılmıştır.

\subsection{Planların dayandığı yasal düzenlemeler}

1920-1940 y1llarını kapsayan “Adapazarı Devlet Ormanlarının Hendek Nâhiyesi Idâre Mıntıkasina Ait Amenajman Lâyiha-i Fenniyesidir" adlı ilk orman amenajman planı, 25.01.1918 tarihinde yürürlüğe girmiş olup, bu planın yasal dayanağını, 1917 tarihli Ormanların Usûl-i İdâre-i Fenniyeleri Hakkında Kânun oluşturmaktadır.

Kanun'un uygulanması ile ilgili yönetmelik, talimatname ve teknik izahnamelerin de ilk defa bu dönemde Avusturya ormancılık mevzuatından da yararlanarak hazırlandığ 1 düşünülmektedir (Kutluk, 1948; Asan, 2013b). Hendek Mustafa Şeref Bey Ormanı için düzenlenen Adapazarı Devlet Ormanlarının Hendek Nâhiyesi İâre Mıntıkasına Ait Amenajman Lâyiha-i Fenniyesidir adlı ilk orman amenajman planın, bu çalışma kapsamında tercümesinin yapılması ile birlikte, planın birçok yerinde teknik ve yasal altlığının Avusturya ormancılığından alındığını ifade eden cümleler yer almaktadır. Örneğin "Hendek Mustafa Şeref Bey Ormanı plan ünitesinin nirengi ağ şebekesi düzenlenirken Avusturya Kadastro Nizamnamesinden yararlanılmıştır.” şeklinde ifadeler tespit edilmiştir.

Türkiye Cumhuriyeti Devleti kurulduktan sonra ormanların planlanması ile işletilmesini düzenleyen ve 1924 y1lında yürürlüğe giren “Türkiye'de Mevcut Bi'l-umûm Ormanların Fenni Usulü İâre ve İsletilmeleri Hakkında Kânun (504 SK)" esas ve kapsam bakımından 1917 tarihli kanun ile oldukça benzerlik göstermektedir. Ancak, Gümüş (2017) tarafından yapılan çalışmada belirtildiği gibi, 1917 yılındaki Kanun sadece devlet ormanlarının işletme planı ile işletilmesine yönelik iken, 1924 yılında çıkarılan 504 sayılı Kanun tüm ormanlar1 kapsamaktadır. Bu iki Kanun temelde bu noktadan ayrışmaktadır. Mustafa Şeref Bey Ormanı plan ünitesinde, I. Devre Orman Amenajman Plan1 (1946) yapılıncaya kadar yeni bir amenajman planı yapılmadığından, 1924 tarihli Kanun ve alt mevzuatın planlama çalışmalarındaki uygulamasıyla ilgili bir sonuç çıkarılamamıştır.

1924 Anayasası'nda ormanlarla ilgili bir hüküm yer almamaktadır (Şimşek, 2016); ancak ormanların devletleştirilmesine olanak sağlayan kamulaştırmayla ilgili 74. maddesi 1937 yılında değiştirilerek, ormanları devletleştirmenin yolu açılmıştır. $\mathrm{Bu}$ düzenleme ile birlikte ormanlarla ilgili bir hüküm ilk defa Anayasa'da yer almıştır.

3116 SK öncesindeki 1917 ve 1924 tarihli kanunların amacı, ülke ekonomisine katkı sağlayacak, verimli ve teknik olarak işletilmeye uygun (yol ve ulaşım alt yapısı, vb.) ormanların amenajman 
planlarını düzenleyip, müteahhitler aracılığıyla işletilmesini sağlamaktır. Bu dönemdeki kanuni düzenlemeler, ormanların bir plan dahilinde işletilmesinin temelini oluşturmaktadır. Diğer bir deyişle, bugünkü planlı ormancılığın esasları ve ormanların amenajman planları ile yönetilmesinin alt yapısı ilk defa 1917 ve 1924 yılında çıkarılan kanunlar ile oluşturulmuştur.

1937 yılında yürürlüğe giren 3116 SK ilk çağdaş Orman Kanunu olarak tanımlanmakta (Şahin 2020) ve 38. maddesi ormanların, orman amenajman planlarına göre "koru” ve "baltalık" olarak işletilebileceği hükmünü içermektedir. Kanunun yürürlüğe girmesiyle, temeli 1917 yılında oluşturulan ve sadece ormanların işletme planları ile işletilmesi esaslarını düzenleyen 504 SK yürürlükten kaldırılmıştır.

1937 ile 1956 arası orman amenajman planlama çalışmalarının yasal dayanağını 3116 SK (38. madde) oluşturur. Orman Işsletme Talimatnamesi ile Devlet Orman İşletme Müdürlükleri'nin kurulma süreçleri başlamasına rağmen, II. Dünya Savaşının devam etmesi ve ormanların Devlet tarafından işletilmesiyle ilgili teknik ve alt yap1 düzenlemeleri tam anlamılla tamamlanamadığı için 3116 SK etkin şekilde uygulanamamış; ancak II. Dünya Savaşının sona ermesiyle güçlü bir şekilde uygulanmaya başlanmiştır.

$\mathrm{Bu}$ amaçla ve öncelikle ülkenin orman varlığının çok kısa sürede belirlenmesi için Avusturya ormancıları tarafından alt yapısı oluşturulan entansif planlama yaklaşımından vazgeçilmiş ve çok daha geniş orman alanlarını planlamayı sağlayan istikşafı planlamaya geçilmiştir. 1941 tarihli Türkiye Ormanlarl Amenajman Planlarının Sür'atIe İkmaline Dair Talimatname tüm ülke ormanlarının kısa sürede amenajman planlarına sahip olmasını amaçlamıştır. Ancak, beklenen sonuç elde edilemediğinden üç yıl sonra planlama çalışmalarını daha fazla hızlandırmak için 1944 tarihli Birinci Devre Amenajman İşleri Talimatnamesi çıkarılmıştır (Şahin, 2020).

1941 yılından 1955 yılına kadar talimatname ve izahnameler ile yapılan planlama çalışmalarının birincil amacı, tüm ülke ormanlarının en kısa sürede plana kavuşturulması, ülkenin orman varlığını belirlenmesi ve uygun ormanların Devlet Orman İşletmeciliği kapsamında işletilmesidir. Plan ünitesinde yapılan Çamdağ Serisi I. Devre Amenajman Planı (1946), Kurtköy Serisi Kat'i Amenajman Planı (1955) ve Kurtköy Serisi Kat'i Amenajman Planı I. Revizyon (1969) planlarının hukuki dayanağını 1937 tarih ve 3116 SK (38. madde) oluşturur; kanunun teknik uygulamaları ise talimatnameler ve izahnameler ile düzenlenmiştir.
27.6.1955 tarihli Orman Amenajman Planlarının Tanzimine ve Tatbikine Ait Talimatname orman envanterine getirdiği yenilikler (hava fotoğrafları ve yersel ölçmelerin birlikte kullanılması ve matematik istatistiğe dayanan orman envanteri) ile Türkiye orman amenajmanında yeni bir çı̆̆ır açmıştır. Yönetmelik yılı 1955 olmakla birlikte, teknik yönergelerin (Arazi, envanter ve harita izahnameleri) hazırlanamaması ve hava fotoğraflarının çekilememesi nedenleriyle uygulamaya ancak 1963 yılında geçmiştir. Asan (2013a) orman planlama konusunda asıl sıçramanın 1973 yılına kadar yürürlükte kalan bu Yönetmelik'le yapıldığını ifade etmektedir.

3116 SK, 31.08.1956 tarihinde yürürlükten kaldırılmış ve yerine 6831 sayılı Orman Kanunu (6831 SK) yürürlüğe girmiştir.

Türkiye ormanlarının planlanması 1955 yılında yürürlük kazanan Orman Amenajman Planlarının Tanzimine ve Tatbikine Ait Talimatname ile standarda kavuşabildiği için 1963 y1lı ormancılıkta Standart Kitlesel Sektör Planlaması'nın başlangıcı olarakta kabul edilmektedir. 1963-1972 arasındaki planlama çalışmaları ile üretilen verilerden yararlanarak ülke orman varlığı orman alanı, serveti, artımı ve ormanların niteliği ile ilgili ilk defa ve kapsamlı olarak ortaya konulmuştur. Ülke ormancılığ 1 ile ilgili geçmiş dönem ve bugünkü orman varlığı karşılaştırmalarında 1963-1972 verileri temel alınmaktadır.

1955, 1973 ve 1991 tarihli Talimatname ve Orman Amenajman Yönetmelik'leri içerik ve kapsam olarak önemli oranda benzerlik göstermektedir. 1955 yılında Talimatname olarak yürürlüğe giren alt mevzuat ilk defa benzer içeriklere sahip olmasına rağmen 1973 yılında Orman Amenajman Planlarının Düzenlenmesi, Uygulanmast, Denetlenmesi ve Yenilenmesi Hakkında Yönetmelik adıyla yürürlüğe girmiş; 1991 yılında yine değiştirilmiş ve aynı isimle yürürlüğe girmiştir. 1973 ve 1991 tarihli Yönetmelikler, yönetmelik ismiyle tanımlanmış olsalar da Tebliğ ve Teknik İzahname işlevlerini görecek şekilde ve kapsamlı hazırlanmışlardır. Plan ünitesinde yapılan Kurtköy Orman İşletme Şefliği Kurtköy Serisi Orman Amenajman Planı (1972), Kurtköy Orman İşletme Şefliği I. Yenileme (1994 ve Kurtköy Orman İşletme Şefliği II. Yenileme (2004) planlarının hukuki dayanağ1nı 6831 SK (26. madde) oluşturmaktadır; teknik uygulamaları ise Talimatname ve İzahnameler ile düzenlenmiştir.

05.02.2008 tarih ve 26778 sayıl1 Resmi Gazete'de yayımlanarak yürürlüğe giren Orman Amenajman Yönetmeliği ilk defa teknik talimatname ve izahnamelerden ayrı olarak hukuki özelliklere sahiptir. 
OGM tarafından yürütülen bu Yönetmeliğin hukuki dayanağını 1956 tarih ve 6831 SK (26. madde) oluşturur. 1973 ve 1991 tarihli Yönetmelikler, hazırlanışları ve Resmi Gazete'de yayımlanmama nedeniyle 1955 tarihli Talimatname ile aynı niteliklere sahiptir. Dolayısıyla 2008 tarihli Orman Amenajman Yönetmeliğ $i$ hukuki metin anlamında ilk yönetmelik kabul edilebilir.

Orman Amenajman Yönetmeliği (2008) ile kapsamı belirlenmiş olan çalışmaların teknik alt yapıS1 ise 2014 tarih ve 299 say1l Ekosistem Tabanl Fonksiyonel Orman Amenajman Planlarının Düzenlenmesine Ait Usul ve Esaslar Tebliği'ne göre gerçekleştirilmiştir. Tebliğ, geçmiş plan dönemlerinde "Talimatname", "Arazi Teknik İzahnamesi" ve "Harita Çizim İahnamesi”" şeklinde hazırlanan tüm alt mevzuatı kapsamaktadır. Plan ünitesinde yapılan Çamdağ 1917 Orman İşletme Şefliği (2015) Planı'nın hukuki dayanağını 1956 tarih ve 6831 SK (26. madde) ile hazırlanan 2008 tarihli Orman Amenajman Yönetmeliği oluşturmaktadır. Kanunun teknik uygulamaları ise 299 sayılı Tebliğ esaslarına göre gerçekleştirilmiştir.

Araştırmanın planlama ünitesi özelinde, yaklaşık yüzyıllık süredeki orman amenajman çalışmalarının mevzuat açısından değerlendirilmesi, Gümüş (2018)'e göre, Osmanlı Devleti'nin son zamanlarından günümüze kadar ormanların kanun ve yönetmelikler çerçevesinde yönetilmesi anlay1Şının devam ettiği şeklindedir. Orman planlama çalışmalarına başlangıçtan itibaren kanuni dayanak oluşturulmuştur. Kanunun uygulamasına ait düzenlemeler ilk planlama çalışmalarından 1973 yılına kadar talimatname ve izahname adiyla gerçekleştirilmiştir. 1973 ve 1991 yıllarında ise teknik talimatname ve yönetmelik hükümlerini kapsayan metinler yönetmelik adıyla hazırlanmış; ancak Resmi Gazete'de yayımlanmadıkları ve yönetmelik hazırlama ilkelerine uymadıkları için 1955 tarihli Talimatname ile aynı özelliklere sahip birer belgedirler. Kanuna ve yönetmelik esaslarına uygun hazırlanan ilk ve tek Orman Amenajman Yönetmeliği 2008 tarihlidir ve halen yürürlüktedir. Orman amenajman çalışmalarının teknik alt yapısı önceki dönemlerde talimatname ve izahname olarak hazırlanan teknik belgelerle sağlanmış, 2014 sonrası ise Orman Amenajman Yönetmeliği'nin hükümlerine karşılık gelen teknik düzenlemeler tebliğ ile düzenlenmiştir.

\subsection{Haritaların oluşturulması ve envanter}

Ülkenin ilk orman planlama ünitesinde 1917 'den 2015'e kadar sekiz plan döneminin hepsinde sınırlar ve alan büyüklüğü, dört defa ise plan ünitesinin ismi değiştirilmiştir. Sınır ve alan değişikliklerinden ötürü, ormanların yapısında meydana gelen konumsal değişimleri, planlama yıllarındaki plan ünitesi sınırlarına bağlı olarak değerlendirmek mümkün olmamaktadır. Şekil 5 incelendiğinde, iki plan dönemi arasında plan ünitesinin hem sınırının hem de alanının değişimine bağlı olarak arazi kullanım tipleri, orman işletme şekli ve verimlilik durumlarında kısa sürede önemli değişimlerin olduğu görülmektedir.

Türkiye'de ormanların kontrolsüz, plansız ve özgürce kullanılmasının sebeplerinden biri de Osmanlı döneminde kullanılan Cibal-i mübaha kavramıdır (Gencay ve Mercimek, 2019) ki, mülkiyet hukuku açısından herkesin ortak mülkiyetinde bulunan mallardır. Osmanlı dönemi ormanlarının büyük bir kısmı bu statüdeydi (Birben, 2009). Plan ünitesi ormanlarındaki serbest faydalanma şekli ormanların sınırlarında, alan büyüklüklerinde, işletme şekillerinde ve verimlilik durumlarında önemli değişikliklerin olmasına neden olmuştur. Bu çalışmada, 1946'ya kadar koru olarak işletilen ormanların (Şekil 5) daha sonraki yıllarda yerini baltalığa bırakması, bu kavramın etkisini yitirmediğini ve halkın ormanları özgürce kullanmaya devam ettiğini göstermektedir.

Ülkenin ilk orman planı 1917 yılında yapılırken orman haritasını yapmaya olanak sağlayacak hiçbir harita altlığ 1 yoktu. Bundan dolayı, amenajman heyetlerinin toplam iş kapasitesinin çok büyük bir kısmı, planı yapılacak ünitenin nirengi ağ sistemi ile harita altlığı ve iç taksimatını oluşturmak için kullanılmıştır. Bu nedenle ancak 1924-1941 arasinda yilda ortalama 100.000 hektara kadar alan planlanabilmiş ve haritası oluşturulabilmiştir. Bu tempo ile Türkiye'de tüm ormanların amenajman planlarını tamamlamanın uzun yıllar sürebileceği dikkate alınarak, daha hızlı sonuç veren esasları ve metotları kullanma yoluna gidilmiştir.

Ülke haritacılığının gelişmesi ve ormancılıkta altlık olarak kullanılan 1/25.000 ölçekli haritaların önce grafik olarak, sonra sayısal harita üretimine olanak sağlayacak halde kullanıma sunulması orman planlamaya önemli katkı sağlamıştır. Harita altlığı, yanı sıra, meşcere haritasının yapımında hava fotoğrafı ve uydu görüntüsü gibi uzaktan alg1lama araçlarından elde edilen materyallerin kullanılması hem planların doğruluk ve güven düzeyini artırmış, hem de daha kısa sürede geniş alanlarda planlama yapılmasının önünü açmıştır.

Planlama sürecinde orman haritasını ve iç taksimatı oluşturmada üç temel haritalama tekniği kullanılmıştır. İlki planlama ekibi tarafından inşa edilen nirengi ağ sistemi olup 1917 yılındaki ilk orman planlamada haritalama ve iç taksimat bu yöntem- 
le gerçekleştirilmiştir. İkincisi, 1/25.0000 ölçekli memleket paftaları altlık olarak kullanılarak, el yardımı ile orman haritasını ve iç taksimatı oluşturmaktır. 1946, 1955, 1969, 1972 ve 1994 planlama çalışmalarında orman haritaları el yardımı ile üretilmiştir. Üçüncüsü ise bilgisayar ortamındaki harita ve görüntülerin bilgisayar yazılımlarıyla sayısal olarak üretilmesidir. Plan ünitesinin ilk sayısal haritası 2004 yılında Netcad, 2015 yılındaki planlamada ise sayısal haritalar ArcGIS yazılımı kullanılarak gerçekleştirilmiştir.

2008 tarihli Orman Amenajman Yönetmeliği yürürlüğe girmesiyle birlikte Harita Çizim İahnamesi hazırlanmış ve bu tarihten itibaren sayısal olarak üretilen orman haritaları standart kazanmıştır. 2015 tarihli haritalar 299 sayılı Tebliğde yer alan Orman Amenajman Plan Haritalarının Bilgisayar Ortamında Çizim Tekniği Yönergesi'ne göre üretilmiştir. $\mathrm{Bu}$ plan döneminde bilgisayar ortamında üretilen orman haritaları ülke genelinde yaygınlaştırılmış ve standart kazanmıştır. Bilgi sistemlerinin ve teknolojilerinin gelişmesi ve CBS (coğrafi bilgi sistemi) yazılımlarının kullanılmasıyla birlikte ormancılık haritalarının üretilmesiyle ilgili önemli gelişmeler sağlanmıştır.

1917 planında örnekleme yöntemi kullanılmamış, tüm bölmeciklerin alanları taranmış ve bölmecik içindeki uygun alanlarda bazı parametreler (bonitet tespiti, deneme ağaç kesim ve ölçümleri vb.) ölçme, bazı parametreler ise (kapalılık ve sıklık, toprak ve yetişme ortamı ile ilgili bilgiler, vb.) gözlemlere dayalı olarak belirlenmiştir. Örneklem yöntemi, 1946 tarihli istikşafı planda havza, 1955 ve 1969 planlarında ise bölme ölçeğinde tecrübe şeritleri yöntemiyle gerçekleştirilmiştir. Plan ünitesindeki orman envanterinde hava fotoğraflarının kullanılması, tecrübe şeritleri yerine matematik istatistiğe bağlı örnekleme yöntemlerinin benimsenmesi ve bonitet tayininde bugün kullanılan yaş ve hâkim ağaçların üst boyunu endeks alan yöntem ilk defa Kurtköy Orman İşletme Şefliği Kurtköy Serisi Orman Amenajman Planı (1972) ile uygulanmıştır. 1955 tarihli Orman Amenajman Planlarının Tanzimine ve Tatbikine Ait Talimatname ile ormancılık planlama çalışmalarına kazandırılan sistematik örnek alan yöntemi ve örnek alanlardan ölçme ve gözlem yoluyla envanter verilerinin toplanması bazı küçük değişikliklerle 1994, 2004 ve 2015 planlama çalışmalarında da kullanılmaya devam etmiştir.

Ülke ormancılık planlamasında, bilgi sistemleri ile teknolojilerinin gelişmesi ve orman haritalarının CBS yazılımları kullanılarak üretilmesiyle oldukça önemli gelişmeler sağlanırken, envanter tekniklerinin geliştirilmesi, veri toplama ve de- ğerlendirme, geçmiş dönem planlarından yararlanarak meşcere hacmi, artım ve servet miktarlarını tahmin etme, modellerden yararlanarak büyüme ilişkilerini saptama, simülasyon ve optimizasyon teknikleri konularında ne yazık ki yeterli gelişme sağlanamamıştır. 1972 yılındaki veri toplama tekniğinin 1994, 2004 ve 2015 planlarında kendini tekrar eder şekilde ve çok daha gevşek uygulandığ1 açıkça görülmektedir.

\subsection{Planlama ilkeleri ve faydalanmanın düzenlenmesi}

Hendek Mustafa Şeref Bey Ormanı (1917) ülkenin ilk orman amenajman planı olmasının yanında, yaş sınıfları yönteminin eşit yaşlı ormanları düzenlemedeki ilk uygulamasıdır. 1946, 1955 ve 1969 planlarında plan ünitesi ormanları çap sınıfları metoduna göre planlanmış; bu ormanlarda yaş sınıfları metodunun ikinci kez uygulanması 1972 planlama çalışmalarıyla gerçekleştirilmiştir. Yaş sinifları amenajman metodu 1994, 2004 ve 2015 planlarıyla 43 yıldır plan ünitesi ormanlarında kesintisiz olarak uygulanmaktadır.

Plan ünitesi ormanları, ilk planlamada koru ve baltalık işletmesi şeklinde planlanmış ve bu işletme şekilleri baltalık işletmeciliğinin bu plan ünitesinde sona erdiği 2006 sonuna kadar devam etmiştir. 2004 planında var olan baltalık işletme sınıfı 2015 planında yer almamaktadır ve geçmişte baltalık olarak işletilen sürgün kökenli ormanlar koru formunda planlanmış; böylece, plan ünitesi ormanlarında 20. yy başlarından itibaren, ısınma ve 1sıtma amaçlı yakacak odunu işletme amacını gerçekleştiren baltalık işletmeciliği son bulmuştur.

İlk dönemlerdeki planlama çalışmalarında ormanların işletme amaçları en yüksek miktarda odunu üretmek ve çeşitli nedenlerle yapısı bozulmuş meşcereleri korumak, ağaçlandırmak ve rehabilite etmektir ve bu durum 1994 planlarına kadar devam etmiştir. 1994 planlarında üretim ormanları, yanı sıra sosyal baskı altındaki ormanlar ve muhafaza karakterli ormanlar farklı işletme sınıflarında planlanmaya başlamıştır. Ormanlar 2004 sonrası ekonomik, ekolojik ve sosyo-kültürel fonksiyonları yerine getirecek işletme amaçları ve koruma hedefleriyle planlanmıştır. Zamana bağlı olarak, işletme amaçları ve işletme sınıfı sayısı artmış ve çeşitlenmiştir. Plan ünitesindeki ormanların odun üretimi dışındaki fonksiyonları 2004 planıyla daha çok dikkate alınmaya başlanmıştır. Ancak planlardaki işletme sınıflarının amaç kuruluşları incelendiğinde, özellikle ekolojik ve sosyokültürel fonksiyonlu ormanların amaç kuruluşlarının ne olduğu ve amaç kuruluşa ulaşmak için hangi silvikültürel uygulamaların yapılması gerektiğiyle ilgili çok 
önemli eksiklikler bulunmaktadır. Son dönemde Ekolojik Tabanlı Fonksiyonel Planlama esaslarına göre yapilan planlamalarda, ekolojik ve sosyokültürel fonksiyonlara göre belirlenmiş işletme sınıfları ne yazık ki alan tahsisinin ötesine çok fazla geçememiştir. Aktüel kuruluş yapısının, belirlenmiş amaç kuruluşuna nasıl ulaştırılması gerektiği ile ilgili çalışmalara ağaç türü ve fonksiyon bazında çok ihtiyaç bulunmaktadır.

1917 ve 2015 arası sekiz planlama döneminde, koru olarak işletilen ormanlardaki ağaç türlerinin idare süreleri oldukça değişiklik göstermiştir (Tablo 1). Özellikle 2004 ve 2015 dönemlerindeki planlar karşılaştırılınca hem ekonomik fonksiyonlu hem de ekolojik ve sosyokültürel fonksiyonlu ormanların idare süreleri, 10 yıl gibi kısa bir zamanda çok büyük değişiklik göstermiştir. İlk plan dönemlerinde ağaç türlerine ait idare süreleri (bazı dönemler amaç çapları da) belirlenirken işletme amaçlarıyla çok daha uyumlu kararların verildiği, son dönem planlama çalışmalarında ise idare süresi ile işletme amaçları ve koruma hedeflerinin uyumlu olmadığı saptanmıştır. Son dönemdeki planlamada ağaç türlerine ait idare süreleri ile ilgili kararlar verilirken yeterince titiz davranılmadığ sonucuna varılmıştır.

Hendek Mustafa Şeref Bey Ormanı (1917) planının önemli bir özelliği her bölmeciğin ayrı silvikültürel işlem ünitesi kabul edilmesidir. Her bölmecik yetişme ortamı özellikleri, aktüel kuruluş yapısı, meşcerelerin ağaç tür kompozisyonu ve karışım oranları bakımından ayrı ayrı ele alınmıştır. Tüm planlarla karşılaştırıldığında, bu planın her bölmecik için önerdiği silvikültürel yaklaşımlar, özellikle meşcere yapısı çeşitli nedenlerle bozulmuş ormanlarda yapılacak silvikültürel uygulamalar ile ormanları iyileştirmeye yönelik uygulamaların çok ayrıntılı verildiği görülmektedir. 1946 planları benzer değişkenleri havza; 1955 ve 1969 planları ise ilk planda olduğu gibi bölme ve bölmecik bazında yüzeysel olarak ele almıştır. 1972 sonrasında ise bu bilgiler plan ünitesinin geneli için toplanmıştır. Her bölmeciğin ayrı bir silvikültür işlem ünitesi kabul edildiği ve meşcerelerin aktüel kuruluş yapısının, yetişme ortamı özelliklerinin ve silvikültürel uygulamaların ayrı ayrı tanımlandığı planların, 1972-2015 yılları arasında silvikültürel uygulamaların esaslarını ve yöntemlerini İşletme Silvikültür Planına göre yapan planlardan çok daha üstün özelliklere sahip olduğu belirlenmiştir. Son dönemlerdeki planlama çalışmalarının bu açıdan gerilediği ve bu durumun silvikültürel planlamanın yetersiz kalmasına neden olduğu düşünülmektedir. İlk orman amenajman planındaki silvikültürel işler, her bölme ve bölmecik için meşcere silvikültür planı niteliğinde ayrı ayrı düzenlenmiştir. Eraslan (1955), silvikültür planı adı ile anılmayan amenajman planının bu kısmının, entansif bir ormancılı̆̆ bile tatmin edecek mükemmeliyette hazırlandığını ifade etmektedir.

1917 tarihli ilk orman amenajman planı ile Kurtköy Serisi Kat'i Amenajman Planı (1955), ağaçların ölçülen parametrelerinden (göğüs çapı, boy ve yaş) yararlanarak plan ünitesindeki asli ağaç türler için kabuklu gövde hacmi ve cari artım tablosu oluşturmuş ve ayrıca her türün şekil emsali belirlenmiştir. Deneme ağaçlarını hacimlendirme yardımıyla ürün çeşitleri tablosu oluşturulmuş, $1 \mathrm{~m}^{3}$ yuvarlak odun ağırlığının yaş ve hava kurusu ağırlığı belirlenmiştir. Bunun dışında ibreli ve yapraklı tür grupları için $\mathrm{m}^{3}$ ü stere ve steri $\mathrm{m}^{3}$ 'e dönüştürme faktörleri hesaplanmıştır. Yaş sınıfları metodu uygulanan 1972-2015 arası planlarda, bu çalışmalar1 plan ünitesi ölçeğinde yapmak çok daha kolay olabilecekken, ne yazık ki planlamalarda bu konular hep ihmal edilmiştir. Belirtilenler, son dönem planlamada en fazla eksikliği hissedilen konuların başında gelmektedir.

Yaş sınıfları metoduna göre düzenlenen, 1917 tarihli ilk orman amenajman planında meşcere orta boyuna göre meşcerenin bonitet sınıfı tayin edilmiştir. Bonitet tayini için Feissmantel ve Pressler'in (OGM, 1917b) bonitet tabloları kullanılmıştır. 1946 tarihli I. Devre Amenajman Planı ile 1955 ve 1969 tarihli Kat'i Amenajman Planları çap s1nıfları yöntemi ile planlanmış ve bu üç planda bonitet tespiti yapılmamıştır. İkinci kez yaş sınıfları metodunun uygulandığ 1972 plan dönemi ile 2004 arasında kayın için bonitet sınıfları iyi, orta ve fena olmak üzere üç sınıfa; 2015 plan döneminde ise beş bonitet sınıfına göre düzenlenmiştir. İlk dönem hariç plan dönemlerinde baltalık işletme sınıfındaki ormanlar için bonitet tespit edilmemiştir. Baltalıklardan koruya ya da koruya tahvile aktarılan orman alanları için de yeni bonitet tespitleri yapılmamış, bu alanların yakınındaki koru meşcerelerinin bonitet endeksleri ile arazi çalışmalarındaki gözlemlerden hareketle bonitet sınıfları saptanmıştır.

Toplumun ormanlardan beklentilerinin farkl1laşmasıyla birlikte, orman ekosisteminin ürettiği odun ve odun dışı orman ürünlerinin yanı sıra, orman ekosisteminin ürettiği hizmetlerin de orman amenajman planlarında yer aldığı belirlenmiştir. Orman amenajman planlarında ekolojik ve sosyokültürel işlevleri gören orman alanlarında zamanla önemli artışların olduğu görülmektedir. Bu durum orman amenajman planlarındaki işletme amaçları ile işletme sınıfı sayısında da artışı ve çeşitliliği getirmiştir. Planlama anlayışındaki bu değişimi, Lane ve McDonald (2002), ormanların planlanma 
amaçlarının, değişen toplumsal ihtiyaçlara ve değerlere göre değişebileceği ve ortaya çıkış zamanlarının ise ülkeden ülkeye farklılık gösterebileceği şeklinde açıklamışlardır.

100 y1llık planlama ufku sonunda ormanın optimale ulaşmadığı görülmektedir. Başlıca nedenleri olarak; uygulanan amenajman metotlarındaki değişiklikler (bir dönem yaş sınıfları, diğer dönem çap sınıfları gibi), plan ünitesi sınırlarındaki değişiklikler (kadastronun tamamlanmaması ve bu nedenle optimal periyodik alanın net olmaması, açmacılık nedeniyle sınırlarda değişiklikler, vs.) ve ormanın orman köylülerinin ana geçim kaynağını oluşturması nedeniyle, ormandan usulsüz faydalanmanın fazla olması sıralanabilir.

Yaşamları ve geçim kaynakları için toprağa güvenen insanlar, ormanların özellikleri hakkında derin bilgiye sahip olma eğilimindedirler (Chazdon ve ark., 2016). Bu durum yöre halkının ormanların planlanmasına, değerlendirilmesine ve izlenmesine önemli ölçüde katkıda bulunabileceğini göstermektedir. Ülkemizde katılımcı planlama yapılabilmesi için adımlar 2008 Yönetmeliği ile atılmış, ancak 100 yıllık orman planlama sürecini tamamlamış ve 8 farklı plan yapılmış plan ünitesi ormanları için katılımeı bir planlama yapılamamıştır. Türkiye'de ormancılık politikaları, planları ve uygulamaları kamuoyu tarafından bilinmediğinden planlama çalışmalarındaki karar verme süreci şeffaf değildir (Atmis ve ark., 2007). Ormancılıkta katılımcı planlama, ormanların planlanması sürecinde şeffaflığın sağlanması için olmazsa olmaz bir yaklaşım haline gelmelidir.

100 yıllık planlama sürecinin başlangıcını oluşturan Hendek Mustafa Şeref Bey Ormanı Planı (1917) ve Çamdă̆ 1917 Orman Işsletme Şefliği Planı (2015) arasında düzenlenmiş tüm planlamalara bakıldığında, çok kriterli karar verme ve matematik disiplinli tekniklerin kullanılmadığı görülmektedir. Sonuç olarak ülkemizde topoğrafik, sosyoekonomik ve çevresel faktörleri dikkate alan daha kapsamlı amenajman planlarını yapabilmek için farklı disiplinlerden modellerin farklı şekillerde birleştirildiği örneklere ihtiyaç duyulmaktadır. Tüm planlama çalışmaları incelendiğinde, özellikle 1972 yılından itibaren kendini tekrar eden ve gelişmenin neredeyse hiç olmadığ 1 planlama sürecinde bu kısmın acilen desteklenmesi gerekir.

Avrupa'da 17. yy ve Amerika'da 18. yy 'da başlayan ormancılıkta planlama çalışmalarının ülkemizde 20. yy 'da başlaması gelişmelerin geriden takip edildiğinin bir göstergesidir. Bu tarihsel vaka incelemesi sonucunda birkaç önemli mesaj ortaya çıkmaktadır ve yeni nesil orman amenajman plan- larının yapılabilmesi için OGM tarafından dikkate alınmalıdır. Araştırma bulgularından yararlanarak varılan sonuç ve öneriler aşağıda verilmiştir;

Orman planlama çalışmalarının sağlam bir hukuki dayanağı bulunmaktadır. Ülkemizdeki orman planlama çalışmalarının en başından itibaren sağlam bir hukuki düzenleme gerçekleştirilmiş ve bu süreç günümüze kadar devam ettirilmiştir. Planlama çalışmalarının yasal dayanağını oluşturan hukuki düzenlemeler (kanun ve yönetmelik) ile teknik altlığını oluşturan (talimatname, tamim, tebliğ ve izahname) teknik mevzuat tüm plan dönemlerinde planlama çalışmalarına yön vermiştir. Geçmişten günümüze kadar süregelen bu olumlu uygulamaların kesintiye uğramaksızın gelecekte de devam ettirilmesi sağlanmalıdır.

Orman planlama ünitelerinin isim, sınır ve alanlarının sürekli değişmemesi gerekir. Plan ünitesindeki orman varlığının nicelik ve nitelik olarak değişimi, geçmiş dönemlerdeki çalışmalara ve uygulamalara ait kayıtlı bilgilerin sağlıklı elde edilmesi, raporlanması ve çok çeşitli sözel, sayısal ve konumsal karşılaştırmalarını yapabilmek için plan ünitesinin sınırları, alanları ve isimleri değiştirilmemelidir.

Mevcut planlama yaklaşımının, zamana bağlı olarak biriken sorunları ötelenmemeli ve köklü çözümler üretilmelidir. Ülkemizdeki planlama yaklaşımına plan ünitesi (Şeflik) ölçeğinin üzerinde ekorejyonlar boyutunda daha makro bir bakış ve planlama anlayışıyla yaklaşılmalıdır. Plan ünitesi ölçeğinde hazırlanan orman amenajman planları, üst ölçekte, geniş katılımlı ve farklı uzmanlıkların birlikte hazırladıkları planlarla uyumlu olarak hazırlanmalıdır. Mevcut amenajman planlarında; envanter teknikleri ve yöntemleri ile tüm plan ünitesi için düzenlenen işletme silvikültür planı ve uygulamalarıyla ilgili önemli sorunlar bulunmaktadır. 1972 plan döneminden sonra ormanın ölçülmesi ile ağaç serveti ve artımın tayinine son derece önem verilmiş, zaman, emek ve bütçe ağırlıklı olarak ormanın ölçülerek haritasının yapılmasına, ağaç serveti ve artımın bulunmasına harcanmıştır. Ormanın bünye ve kuruluşuna, yetişme ortamı verim gücünün belirlenmesine, idare sürelerinin ve işletme amaçlarının amaç kuruluşuna uygun olarak saptanmasına, açıklıkların, boşluklu ve gevşek kapalı ormanların imarı ve iyileştirilmesine yönelik silvikültürel yaklaşımların ve uygulamaların neler olması gerektiği ile ilgili işler amenajman planlarında oldukça yüzeysel verilmektedir. Planların yapılma biçimi, yürürlükteki Orman Amenajman Yönetmeliği'nin ekosistem tabanlı fonksiyonel planlama yaklaşımıyla çelişmektedir. Teknik mevzuat olarak gayet iyi hazırlanmış planlama 
yaklaşımının ne yazık ki bir türlü içi doldurulamamış ve amenajman planları fonksiyonel alan tahsisi yapan kesim planları niteliğine bürünmüştür.

Yeni yaklaşımlar, bilgi sistemleri ve teknolojik gelişmelere ayak uydurulmalı, yeni nesil orman amenajman planları ile farklı disiplinlerin güçleri birleştirilmelidir. Ülke ormancılık planlamasında, bilgi sistemleri ile teknolojilerinin gelişmesi ve orman haritalarının CBS yazılımları kullanılarak üretilmesiyle oldukça önemli gelişmeler sağlanmıştır. Farklı disiplinler (bilimler) güçlerini birleştirdiğinde, örneğin hava fotoğrafları ve uydu görüntüleri gibi uzaktan algılama verilerinin orman envanteri çalışmalarında kullanılması, ağaç türlerinin meşcere sınırlarını, vb. tahmin etmek ve modeller oluşturmak için kullanılmasıyla orman envanterinde önemli ilerlemeler meydana gelmiş ancak bunların çok az kısmı planlama çalışmalarına yansımıştır. Envanter tekniklerinin geliştirilmesi, veri toplama ve değerlendirme, geçmiş dönem planlarından yararlanarak meşcere hacmi, artım ve servet miktarlarını tahmin etme, modellerden yararlanarak büyüme ilişkilerini saptama, simülasyon ve optimizasyon teknikleri konularında ise yeterli gelişme sağlanamamıştır. Her ne kadar ülkemizde model planlar hariç örneğine rastlanmasa da simülasyon, optimizasyon, ekonomik modeller, vb. konularında çalışan farklı disiplinlerden de yararlanmalı ve bu alanlarda işbirliği yapılmalıdır. Yeni teknolojiler, yeni nesil orman amenajman planı modelleri, verileri ve bilgi sistemleri geliştirilmeli ve planlamacılar tarafından benimsenmelidir.

Planlamada kullanılan veriler açık ve önceki-sonraki plan dönemi ile uyumlu olmalıdır. Amenajman planı verilerini kullanarak farklı modellerin geliştirilebilmesi veri setlerinin düzenli ve uyumlu olmasına bağlıdır. Her plan döneminde yeni veri setlerinin oluşturulması ve verilerin önceki plan dönemi ile uyumlu olması araştırmacılara yardımcı olacak ve planlamada ülkemiz için yenilikçi çalışmalar ortaya çıkabilecektir.

Planlar katılımcı yaklaşım ile yapılmalıdır. Ormanlardan beklenen ürün talebinin yerini zamanla hizmet talebine birakmasiyla toplumun ormanlar üzerinde söz sahipliği artmıştır. Belediyeler, sivil toplum kuruluşları, araştırma enstitüleri, yörehalk1, vb. söz sahipleri ormanlar planlanırken ne derece duyarlı oldukları ve bilimsel yaklaşımların uygulandığını görmeleri hem Orman Teşkilatına karşı güvenlerini arttıracak hem de toplumun görüşlerinin hesaba katılması ormanlara karşı toplumsal bilinç ve duyarlılığ 1 arttıracaktır.

\section{Teşekkür}

Bu makale, Orman Genel Müdürlüğü, Marmara Ormancılık Araştırma Enstitüsü Müdürlüğünce yürütülen 10.3302/2016-2018 numaralı “Türkiye'nin İlk Orman Planlama Ünitesindeki Zamansal ve Konumsal Değişimin Yüz Yıllık Analizi” isimli Proje Sonuç Raporunun (Şahin ve ark., 2019) bir bölümünün özetidir.

Projenin yürütücü kuruluşu olan Marmara Ormancılık Araştırma Enstitüsü Müdürlüğü ile destekleyen birimler olarak projede yer alan Orman Genel Müdürlüğü, Orman İdaresi ve Planlama Dairesi Başkanlığı ve Sakarya Orman Bölge Müdürlügü’ne projeye vermiş olduğu her türlü desteklerinden dolayı teşekkür ederiz. Ayrıca, 1917 ve 1972 yıllarına ait meşcere haritalarının vektör veriye dönüştürülmesi ve verilerin veri tabanına işlenmesi, planlarının taranması konularında bu projeye katkılarından dolayı orman mühendisleri Uğur MEMIȘ, Mine AKCAN ve Ümit KORKMAZ'a teşekkürü borç biliriz.

\section{Kaynaklar}

Agnoletti, M., Anderson, S. 2000. Methods and approaches in forest history (C. 3). CABI

Asan, Ü., 2013a. Ormancılığımızın Sektörel Planlaması 50. Y1lına Girerken Orman Amenajmanı Temel Kavramlarında Ortaya Çıkan Yeni Yaklaşımlar. Ormancılıkta Sektörel Planlamanın 50. Y11ı Uluslararası Sempozyumu, 30-42, 26-28 Kasim 2013, Antalya

Asan, Ü., 2013b. Orman amenajmanı esasları (temel kavramlar, amaçlar ve ilkeler). İ.Ü. Orman Fakültesi Yayını, No: 5146/502. ISBN: 978-975-404-933-6 Bahçeköy, İstanbul.

Atmis, E., Ozden, S., Lise, W. 2007. Public participation in forestry in Turkey. Ecological Economics, 62(2): 352-359.

Axelsson, A.-L., Östlund, L. 2001. Retrospective gap analysis in a Swedish boreal forest landscape using historical data. Forest Ecology and Management, 147(2-3): 109-122

Barbero, M., Bonin, G., Loisel, R., Quézel, P. 1990. Changes and disturbances of forest ecosystems caused by human activities in the western part of the Mediterranean Basin. Vegetation, 87(2): 151-173

Baskent, E. Z., Terzioglu, S., Baskaya, Ş. (2008). Developing and implementing multiple-use forest management planning in Turkey. Environmental management, 42(1): $37-48$

Birben, Ü. 2009. Cibal-i Mübaha. II. Ormanc1lıta Sosyoekonomik Sorunlar Kongresi, 19-21 Şubat 2009, 
Bildiriler Kitab1. ISBN 978-9944-452-28-1, s:395-404 SDÜ, Isparta,

Brosofske, K. D., Froese, R. E., Falkowski, M. J., Banskota, A. 2014. A review of methods for mapping and prediction of inventory attributes for operational forest management. Forest Science, 60(4): 733-756

Bürgi, M. 1999. A case study of forest change in the Swiss lowlands. Landscape Ecology, 14(6): 567-576

Chazdon, R. L., Brancalion, P. H. S., Laestadius, L., Bennett-Curry, A., Buckingham, K., Kumar, C., ... Wilson, S. J. 2016. When is a forest a forest? Forest concepts and definitions in the era of forest and landscape restoration. Ambio, 45(5): 538-550

Eler, Ü. 2008. Türkiye'de Orman Amenajman Yönetmeliği'nin tarihsel gelişimi. Süleyman Demirel Üniversitesi Orman Fakültesi Dergisi Seri: A, Say1: 2, Y11: 2008, ISSN: 1302-7085, Sayfa: 89-98

Eraslan, İ. 1955. Türkiye'de yapılan ilk amenajman planının analitik ve kritik olarak incelenmesiyle varılan neticeler İstanbul Üniversitesi. Orman Fakültesi Dergisi, 5: 199-221

Eraslan, İ. 1982. Orman Amenajmanı. İ.Ü. Orman Fakültesi Yayın1, No: 3010/318 Bahçeköy, İstanbul.

Gencay, G., Mercimek, A. 2019. Public consciousness and influence of law on forest crimes: Insights from Kastamonu, Turkey. Forest Policy and Economics, 106: 101978

Gümüş, C. 2017. Devlet Ormanc1lı̆̆ına Geçiş Sürecinde Karadere Serüveni. Türkiye Ormancılar Derneği (TOD, ISBN 978-605-64482-6-3, Ankara

Gümüş, C. 2018. Türk Orman Devrimi. Türkiye Ormancılar Derneği (TOD Yayın No: 43, ISBN 978-60568977-0-2, Ankara

Hall, B., Motzkin, G., Foster, D. R., Syfert, M., Burk, J. 2002. Three hundred years of forest and land-use change in Massachusetts, USA. Journal of Biogeography, 29(10-11): 1319-1335

Kennedy, J. J. 1985. Conceiving forest management as providing for current and future social value. Forest Ecology and Management, 13(1): 121-132

Kutluk, H. 1948. Türkiye Ormancılığı ile ilgili Tarihi Vesikalar. Cilt: 1. Istanbul. Orman Umum (Genel) Müdürlüğü

Lane, M. B., McDonald, G. 2002. Towards a general model of forest management through time: Evidence from Australia, USA and Canada. Land Use Policy, 19(3): 193-206

Mather, A. S. 2001. Forests of consumption: Postproductivism, postmaterialism and the postindustrial forest. Environment and Planning: Government and Policy,
19(2): $249-268$

Paletto, A., Sereno, C., Furuido, H. 2008. Historical evolution of forest management in Europe and in Japan. Bulletin of Tokyo Univ For, 119: 25-44

Schmithüsen, F. J. 2013. Three hundred years of applied sustainability in forestry". Working papers/Forest Policy and Forest Economics/International series, Unasylva 2013/1, Volume 64 No 240: 3-11. Zurich I Switzerland

Southgate, E. W. B. 2019. People and the land through time: Linking ecology and history, 2nd Edition". Yale University Press. https://books.google.com.tr/ books?id=Jy-oDwAAQBAJ (Erişim Tarihi: 03.11.2020)

Şahin, A. 2020. Türkiye'de İlk Orman Haritasının Üretilmesinden Günümüze, Ormancilıkta Haritanın Kullanımı ve Ülke Haritacılığının Gelişimine Katkısı. TMMOB Harita Kadastro Mühendisleri Odası İstanbul Şubesi Yayını, Say1:2, ISSN: 2717-7947, s: 49-64, İstanbul.

Şimşek, O. 2016. Türkiye'nin planlama ile tanışması: Devletçilik dönemi üzerine bir inceleme. Artvin Çoruh Üniversitesi Uluslararasi Sosyal Bilimler Dergisi, 3: 1-21, Artvin

Vos, W. 1996. Changing forest functions in NW Europe: from alienation to involvement. Içinde: Forestry in the context of rural development: future research needs. EFI Proceedings 15: 127-139

\section{Arşiv Kaynakları (Kanun, alt mevzuat ve planlar)}

Ormanların Usûl-i İdâre-i Fenniyeleri Hakkında Kânun, Takvim-i Vekâyi'nin 2 Receb 1335/24 Nisan 1333 [24 Nisan 1917] tarih ve 2863 say1

504 SK. Türkiye'de Mevcut Bilumum Ormanlartn Fenni Usulü İdare ve İșletmeleri Hakkında Kanun (Kanun No. 504). Resmi Gazete (18 Ramazan 1342/22 Nisan 1342[24.05.1924]

3116 SK. 3116 sayll Orman Kanunu (08.02.1937 tarih ve 3537 sayıl1 Resmi Gazete)

6831 SK. 6831 sayll Orman Kanunu (08.09.1956 tarih ve 9402 sayıl1 Resmi Gazete)

OGM, 1917a. Orman Genel Md. Orman Amenajman Yönetmeliği Tasarısı (Devlet Ormanlarına Ait Amenajman Talimatnamesi (Kaynak: Kutluk, H. 1948. Türkiye Ormanc1lığ ile İlgili Tarihi Vesikalar. C: 1. Istanbul).

OGM, 1924. Orman Genel Md. Orman Amenajman Yönetmeliği Tasarıss (Devlet Ormanlarına Ait Amenajman Talimatnamesi)

OGM, 1941. Orman Genel Md. Türkiye Ormanları Amenajman Planlarının Sür'atIe İkmaline Dair Talimatname

OGM, 1944. Orman Genel Md. Birinci Devre Amenajman İsleri Talimatnamesi 
OGM, 1946a. Orman Genel Md. Orman Etüdleri ve Amenajman İş Kılavuzu

OGM, 1952. Orman Genel Md. Orman Amenajman Planlarının Tanzimine ve Tatbikine Ait Talimatname. Ankara

OGM, 1955a. Orman Genel Md. Orman Amenajman Planlarınin Tanzimine ve Tatbikine Ait Talimatname

OGM, 1973. Orman Genel Md. Orman Amenajman Planlarının Düzenlenmesine, Uygulanmasina ve Yenilenmesine Dair Yönetmelik

OGM, 1991. Orman Genel Md. Orman Amenajman Planlarının Düzenlenmesi, Uygulanması, Denetlenmesi ve Yenilenmesi Hakkında Yönetmelik

OGM, 2008. Orman Genel Md. Orman Amenajman Yönetmeliği (Ekosistem Tabanl Fonksiyonel Planlama) (05.02.2008 tarih ve 26778 sayılı Resmî Gazete)

OGM, 2014. Orman Genel Md. Ekosistem Tabanll Fonksiyonel Orman Amenajman Planlarının Düzenlenmesine Ait Usul ve Esaslar Tebliği (Tebliğ No: 299)

OGM, 1917b. Orman Genel Md. Adapazarı Devlet Ormanlarının Hendek Nâhiyesi İdâre Mıntıkasına Ait Ame- najman Lâyiha-i Fenniyesidir (Hendek Mustafa Şeref Bey Ormanı (1920-1940)

OGM, 1946b. Orman Genel Md. Çamdă̆ Serisi I. Devre Amenajman Planı (1946-1947)

OGM, 1955b. Orman Genel Md. Kurtköy Serisi Kat'i Amenajman Planı (1955-1964)

OGM, 1969. Orman Genel Md. Kurtköy Serisi Kat'i Amenajman Planı I. Revizyon (1969-1972)

OGM, 1972. Orman Genel Md. Kurtköy Orman Ișsletme Şefliği Kurtköy Serisi Orman Amenajman Planı (19721991)

OGM, 1994. Orman Genel Md. Kurtköy Orman Issletme Şefliği Orman Amenajman Planı I. Yenileme (1994-2003)

OGM, 2004. Orman Genel Md. Kurtköy Orman İsletme Şefliği Orman Amenajman Planı II. Yenileme (20042013)

OGM, 2015. Orman Genel Md. Çamdağ 1917 Orman Işletme Şefliği Ekosistem Tabanlı Fonksiyonel Orman Amenajman Planı (2015-2034) 